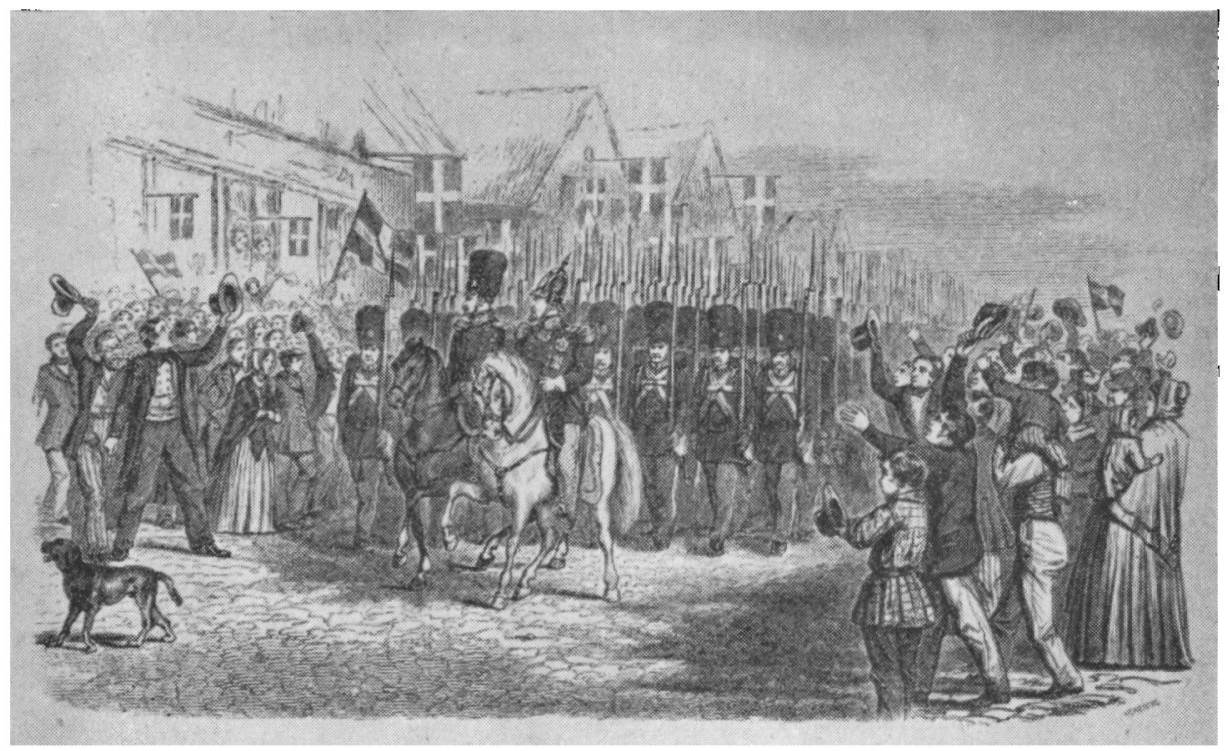

Frederik VII's indtog i Flensborg dagen efter slaget ved Bov.

\title{
Flensborg under slesvig-holstensk styre i 1848.49
}

\section{Af Holger Hjelholt}

1. Den nationalpolitiske stilling i Flensborg forud for oproret.

Om de nationalpolitiske forhold i Sønderjyllands største og vigtigste by, Flensborg, udtaler $P$. Lauridsen i sit berømte værk: „Da Sønderjylland vaagnede“ (bd. 7, 1922), at den offentlige mening $i$ tiden forud for revolutionen 48 beherskedes af det dansksindede eller loyale parti. Men helt betydningsløs var den slesvig-holstenske bevægelse ikke. Dens mest fremtrædende repræsentant var advokaten Jürgøn Bremer, født i Adelby, fra i 828 bosat i Flensborg. Om en af hans tilhængere, en rådstuebetjent Lohse, siges det, at han ved en fest udtalte: Lohse heisse ich, aber fest stehe ich und halte an der Streitaxt Bremer! Det samme gjorde adskillige andre, ikke blot af gejstlige eller verds- 
lige embedsmænd, der i Kiel havde indsuget slesvig-holstenske teorier eller ved andre tyske universiteter var blevet henforte af stortyske fremtidsplaner. Også en del flensborgske købmænd og erhvervsdrivende havde rettet deres blik mod syd, således oliemøller Nane Jürgensen. Denne grundærlige mand, siger en dansk flensborger, troede så urokkelig på den slesvig-holstenske sags retfærdighed, at han vilde have ladet sit liv for den, ligesom han ofrede en del af sin formue for at stotte den.

Langt de fleste af byens købmænd og rhedere anså dog forbindelsen med Danmark for en livsbetingelse for deres matericlle eksistens - og vedgik deres interesse for denne. Deres handel gik på København, deres skibe fòr på Grønland eller Vestindien. De vilde ikke have noget at gøre med den statsopløsende slesvig-holstenske bevægelse. De var loyale, kongeligsindet eller "statsborgerligsindet“, men derfra og til at være „ejderàansk" eller dansksindet i kulturel forstand var der et spring. I Flensborg havde tysk sprog jo fået overtaget hos de velstillede og „:dannede“, selv om „flensborgtysk“ nok kunde vække forbavselse og fremkalde spottegloser hos „rigtige“ tyskere.

Men det var ikke blot den velhavende købmandsstand, der fastholdt den gamle forbindelse med Danmark og levede efter mottoet: "vi vil forblive, hvad vi er", det trivielleste af alle mottoer, som den tysksindede flensborgske præst ved Mariekirken. C.A.Valentiner, kalder det. Også hovedmassen af den lavere befolkning hyldede dette motto og var konge og fædreland tro hengivne. Derfor lyder taien fra tysk side tit om den dansksindede „pøbel“. En karakteristisk tysk udtalelse om denne overensstemmelse i sindelaget hos smảfolk og storkøbmænd finder vi i et bladindlæg fra marts 49 , hvor der spottes over den hyklerske nedladenhed, hvormed de dansksindede købmænd hilste selv „proletaren“, når han blot tilhørte samme parti! Noget hykleri behøver der så vist ikke at være heri. Den fælles nød nedbryder klasseforskellene.

Af betydning for den politiske indstilling hos den flensborg- 
ske befolkning har det sikkert været, at den i ikke ringe grad er blevet rekrutteret af tilflyttere fra det dansktalende opland eller fra selve kongeriget. De nøje handelsforbindelser måtte fremme en sådan. Det skal også nævnes, at talrige tjenestefolk i Flensborg var kongerigske.

Det svarer meget godt til disse synsmåder, at Flensborgs to repræsentanter i den slesvigske stænderforsamling var loyale, "statsborgerligsindede" mænd. Den ene var agent $H$. C. Jensen, der allerede valgtes i $1834 \mathrm{og}$ siden stadig genvalgtes. Han var tillige rådmand og spillede en stor rollei Flensborgs handelsforening. Den anden stænderdeputeret var fra 1838-47 rådmand Feter Nielsen, der ved sin dod i sidstnævnte år efterfulgtes af sin svigersen $H$. P. Schmidt.

Vi vil i det følgende komme til at omtale en række dansksindede, fremtrædende flensborgere. Jeg skal allerede her nævne nogle navne. Først grosserer Andreas Christiansen, leder af handelshuset af samme navn. Han gik med liv og sjæl op i arbejdet for danskheden, og $i$ hans velstillede hjem færdedes de danske forere som Flor, L. Skau o. a. Han var i tiden før 48 chef for borgerkorpset den kgl. Christiansgarde i Flensborg og formand for den slesvigske forenings afdeling for Flensborg og omegn. En anden ivrig forkæmper for den nøje forbindelse med Danmark var Christian Hansen jun., der efter at have været købmand fik stillingen som broskriver. Han var en vældig talsmand for den slesvigske tværbane, et projekt, der dog først udførtes i 50'erne, og han var en god pennefører for den atter og atter gentagne synsmåde, at Sønderjylland økonomisk stod sig bedst ved forbindelsen medDanmark. Af andre fremtrædende danske kan nævnes lægen J. F. Duseberg, købmændene Claus Schwennsen og J. W. H. Jochimsen samt advokat M. F. Blaunfeldt, der var født i Åbenrå, men virkede som advokat i Flensborg fra 1831 og tillige som medarbejder ved den af A. S'. Kastrup udgivne Flensburger Zeitung. En betydningsfuld rolle spillede og. så hjulmager Johan Kruse, der var født i Ekernførde, men først 
i 30'erne kom til Flensborg. Han fik megen indflydelse i. de bredere lag og blev i begyndelsen af 40'erne oldermand for St. Knudsgildet.

En bekræftelse på P. Lauridsens synspunkt, at den offentlige mening i Flensborg før oprøret beherskedes af det dansksindede eller loyale parti, finder vi i nogle udtalelser, som fremsattes af den slesvig-holstenske politimester Krohn sidst på året 48, da han havde regeret i Flensborg nogle måneder. Der er derfor grund til at nævne dem allerede $\mathrm{nu}^{1}$ ). Før revolutionen, udtaler Krohn, havde de tysksindede flensborgere en meget trykket stilling - mere end i nogen anden nordslesvigsk by. De dansksindede og deres ordførere havde derimod erhvervet sig betydelig indflydelse. Blandt disse ordførere nævner Krohn købmand Claus Schwennsen, filialbankens bogholder Fr. Torm, stenhuggermester Klewing og købmand Jochimsen. Det herskende danske parti havde ogsả fået besat de små kommunale stillinger med Andreas Christiansens eller ligesindedes "kreaturer". I magistraten havde det endvidere en indflydelsesrig repræsentant $\mathrm{i}$ rådmand $\mathrm{H}$. C. Jensen, der vel var alle andre magistratsmedlemmer overlegen i forstand, og om hvem det desuden var bekendt, at han stod i brevveksling med Christian VIII. En betydningsfuld rolle for tilknytningen til Danmark spillede endelig filialbanken.

Men den danske stilling i Flensborg havde et svagt punkt, hvor man måske mindst skulde have ventet det. Det var hos de af regeringen selv udnævnte embedsmænd! Man synes, at regeringen kunde have taget lidt hensyn til den nationalpolitiske indstilling ved udnævnelserne, og at $\mathrm{i}$ øvrigt embedsmændenes aflagte troskabsed burde sikre mod tilslutning til en revolution. Men det skulde vise sig ikke at være tilfældet. En af de slesvigholstensksindede præster, den førnævnte Valentiner ved Mariekirken, var senere meget forarget over, at man vovele at foreholde ham den til kongen aflagte ed, ja endog „rive ham den $i$

1) Krohns beretning vil blive trykt i Danske Magazin. 
næsen"! Ja, folk kan være onde. - Forklaringen på embedsmændenes indstilling ligger imidlertid, som før antydet, i deres uddannelse ved Kiels universitet. I Flensborg var flere af præsterne med provsten Volquardts i spidsen slesvig-holstenere, og det samme gjaldt nok et par af lærerne ved latinskolen.

Også i magistraten havde regeringen ved sine udnævnelser givet de slesvig-holstenske synsmåder en ganske god repræsentation. Om udnævnelse af aktive revolutionsmænd var der dog ikke tale. $\mathrm{Da}$ det vigtige embede som førsteborgmester i 1845 blev ledigt, søgte professor Christian Paulsen dette embede i "min kjære dansksindede fødeby“, som han skriver i sin dagbog. Christian VIII udnævnte imidlertid ikke Paulsen, men en mand fra centraladministrationen i København, C. F. Callisen, der var født i Slesvig som søn af den senere generalsuperintendent, og som havde fået sin uddannelse i Kiel. Callisen blev byen en dygtig og sparsommelig borgmester. Hans politiske anskuelser var konservative, men med hældning mod slesvig-holstenismen. En lignende holdning indtog bysekretæren O. D. Holm og politimester Fr. Aug. Niemann, den sidste fadt i Kiel og udnævnt til politimester i 1838. Holms og Niemanns mere moderate slesvig-holstenisme slog ud i lys lue hos deres børn. Således meldte en af Niemanns sønner sig straks ved oprørets udbrud til det slesvig-holstenske frikorps.

\section{Oprorets udbrud. Den forste slesvig-holstenske besættelse}

\section{7. marts-9. april 1848.}

Modet i Rendsborg den 18. marts 1848, hvortil de slesvigholstenske førere havde indkaldt de stænderdeputerede både fra Slesvig og Holsten, blev optakten til revolutionen. På dette møde vedtog man at stille en række krav til regeringen, hvilke en deputation til København skulde søge opfyldt. Kravene gik bl. a. ud på en fælles slesvig-holstensk forfatning og Slesvigs optagelse $i$ det tyske forbund, noget, der statsretligt vilde være et brud med Sønderjyllands hele historie. Ved mediat var af Flens- 
borgs to deputerede H. P. Schmidt til stede; han var fulgtes dertil med nordslesvigeren $\mathrm{H}$. A. Krüger, hvis djærve protest mod de af forsamlingen tagne beslutninger er gået over i historien.

Slesvig-holstenerne afventede ikke den afsendte deputations tilbagekomst fra København. Natten mellem den 23. og 24. dannedes i Kiel den provisoriske regering, hvoraf også advokat Jürgen Bremer i Flensborg blev medlem²). Bremer var dog ikke selv i Kiel ved dannelsen af regeringen. Den 24. udstedte denne det kendte opråb om, at landsherrens vilje ikke længere var fri og landet uden regering, hvorfor altså „den provisoriske“ havde grebet tøjlerne. I slutningen hed det, at man med al kraft vilde slutte sig til Tysklands enheds- og frihedsbestræbelser. Overalt i Tyskland var revolutionen jo også brudt ud. - Samme dag sendte den provisoriske regering en rundskrivelse til de forskellige myndigheder og opfordrede dem under henvisning til opråbet til at fortsætte deres virksomhed i henhold til de bestående love. Endvidere anmodedes der om omgående at meddele, at man havde modtaget denne rundskrivelse.

Skrivelsen kom først til Flensborg om morgenen den 26.,en søndag. Men allerede dagen før havde bykollegierne været samlet og drøftet spørgsmålet om anerkendelse af den provisoriske regering $i$ anledning af dennes proklamation ${ }^{3}$ ). Man besluttede imidlertid at udsætte sagen i hvert fald, til man havde fået en officiel meddelelse fra nævnte regering. Men, som det hedder i byens protokol, for at berolige borgerne vedtog man at offentliggøre en erklæring om, at man vilde have Slesvigs hidtidige stilling og dets forbindelse med Holsten opretholdt. Erklæringen publiceredes straks ved trykte sedler. De borgere, der skulde beroliges, var jo navnlig de aktive slesvig-holstenere, der trængte på med krav om tilslutning til revolutionen. I ørigt dækker

2) Denne begivenhed har jeg nærmere skildret i årgangen 1937.

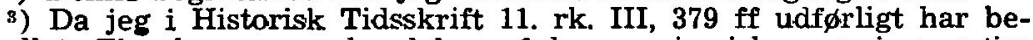
handlet $\gg$ Flensborgs »anerkendelse» af den provisoriske re:gering $\ll$, n $\varnothing j$ es jeg her med en kort omtale. 
erklæringen vist meget godt førsteborgmesterens egen politiske holdning.

Den følgende morgen, da den provisoriske regerings skrivelse var indløbet, vedtog bykollegierne enstemmigt "anerkendelsen“. Samtidig offentliggjordes en erklæring om, at en række institutioner stod under borgerskabets beskyttelse, og at ingen af indbyggerne vilde blive udsat for overlast på grund af sine politiske meninger. Dette var dog lettere at love end at holde.

P. Lauridsen siger om denne beslutning, at det lykkedes Callisen at liste en anerkendelse igennem, men af ringe værd. Ordet "liste" vil jeg ikke just bruge herom, men det er rigtigt nok, at $i$ en vis forstand var anerkendelsen af ringe værd. Den beted nemlig ingen tilslutning til den provisoriske regerings program, det var ingen „anerkendelse“ af dens lovlighed eller berettigelse. Men det var en tilkendegivelse af, at man dels for at undgå indre uro, dels $i$ forventning om den kommende slesvigholstenske besættelse vilde rette sig efter den nye regerings bestemmelser. Da magistraten efter slaget ved Bov skulde forsvare „anerkendelsen“ overfor den danske regeringskommission, sker det også ved at anføre disse synsmåder.

Drastisk fremstilles situationen i en af toldinspektør, kaptajn C. E. Oehl i Flensborg afgiven erklæring om, hvorfor han havde anerkendt "den provisoriske“: kongens regering havde ladet sine embedsmænd helt i stikken, og den provisoriske regering kunde $i$ et tidsrum af 8-14 dage få sine befalinger adlydt ved hjælp af terroristiske, med udstrakte fuldmagter forsynede kommissærer og ved hjælp af en mængde bajonetter, det i denne tid ene virkningsfulde middel! - Forholdet var jo det, at slesvigholstenerne i den første tid havde det militære initiativ, og at regeringen ikke - trods mange advarsler — i tide havde truffet forberedelser til at imødegå revolutionen.

Magistraten anerkendte nok den provisoriske regering som en faktisk bestående; men lyst til at støtte den i en krig med Danmark havde den sandelig ikke. Samme dag som anerkendel- 
sen sendte den en skrivelse til "den provisoriske“ af folgende indhold: Flensborgs merkantile interesser knytter sig i høj grad til Danmark. Næsten alle vore købmænds handel går for største delen på Danmark, og sikkert mange har her næsten hele deres formue stående ude. „Dette er synspunkter, som kræver den største hensyntagen". Magistraten lagde "den provisoriske" dette på hjerte, for at om gørligt ethvert skridt kunde undgås, der kunde indvirke direkte forstyrrende herpå! Noget resultat af denne henvendelse opnåedes ikke.

Om aftenen den 27. rykkede de første slesvig-holstenske tropper ind i Flensborg. De følgende dage fulgte andre afdelinger, og hæren, der stod under generalmajor August Krohn, tog stilling lige nord for byen. Fra 1. april var major von Unzer kommandant i byen. Denne fik ved den militære indkvartering og rekvisitioner samt handelens standsning krigens følger at mærke. En virkning af krigen var det også, at latinskolen gav ferie før tiden, og at kirkebesøget stærkt dalede de følgende søndage.

Trods magistratens løfte om beskyttelse af borgerne, dansksindede som tysksindede, blev et par af de mere fremtrædende danske udsat for overlast. Gentagne gange fandt der således pøbeloptøjer sted ved Andreas Christiansens hus; man vilde have ham til at hejse den trefarvede fane, hvad han nægtede. Lignende opfordringer afvistes af den kongetro og loyale pastor Asschenfeldt ved Nikolaj kirke, skønt han om aftenen den 2. april i den anledning fik besøg $i$ "sit stille hus" af 6 berusede slesvig-holstenske soldater. Advokat Blaunfeldt, der vilde bringe sig i sikkerhed i København, blev stoppet og ført fangen til Rendsborg, hvorfra han senere frigaves. Kruse, som havde hørt tale om, at han skulde sendes samme sted hen, slap dog denne gang. Ved en henvendelse til borgmesteren forsikrede denne ham også om, at han indestod for hans sikkerhed.

Om de slesvig-holstenske soldaters opforsel i Flensborg udtaler pastor Asschenfeldt ud fra sit loyale standpunkt, at den 
vidnede om dårlig samvittighed: de var som besatte af en vanvittig ulydigheds rus og sogte at døve deres samvittighed ved larmen og brændevin: „På en sådan måde kæmper man ikke for nogen god og lovlig sag“. - Den flensborgske amtmand C. L. v. Warnstedt, der ved oprørets udbrud gik den provisoriske regerings ærinder, omtaler i et brev 5 . april til den gottorpske amtmand Liliencron, at de tyske tropper er helt udisciplinerede. Efter slaget ved Bov, da han overfor de danske myndigheder skulde forsvare sin optræden, taler han om de nævnte troppers tøjlesløshed.

Anerkendelsen af den provisoriske regering fremkaldte harme i store dele af byens befolkning, og det hævdes, at det nær var kommet til uroligheder endnu før danskernes indtog den 9. april. Politimester Niemann måtte efter magthavernes ordre foretage undersøgelser vedr. et enkelt tilfælde med hejsning af Dannebrog og vedr. kuglestøbning, men undersøgelserne endte uden straf for de pågældende. Ved Skibbroen blev en sypige, der havde hængt den tyske fane ud af sit vindue, genstand for smædeord fra en flensborgsk rorskarl, der vilde have hende til at tage flaget væk, og som desuden skal have fået gadedrengene til at kaste sten på hendes vinduer. For disse bedrifter slap han dog med en advarsel.

Niemanns undersøgelse vedr. flagning med Dannebrog gjaldt vist en episode, der inàtraf den 28. $\mathrm{Da}$ det danske dampskib Gejser denne dag viste sig i havnen, morede bogtrykker Kastrups små børn sig med at stikke et lille Dannebrogsflag ud af vinduet. Episoden omtales $i$ en skrivelse af samme dag fra regeringskommissæren Carl Ferdinand Jacobsen til magistraten, der opfordres til ufortovet at skride ind. Jacobsen anbefaler desuden indtrængende magistraten at vise en beslutsom og kraftig optræden „i vort fædrelands engang for retfærdig anerkendte sag, som den provisoriske regering repræsenterer, og som dog i sandhed også er vor ulykkelige af en Lehmann og fæller tvungne landsherres sag. Halve forholdsregler, al lunken- 
hed kan blot være fordærvelıg for byen selv; de sidste 4 ugers erfaring har dog til overflod vist, at der kun er frelse $i$ beslutsomhed". - Det var ord, som hos magistraten sikkert er faldet på stengrund.

Der foreligger et par andre skrivelser af den 28. fra Jacobsen til magistraten. Den ene omhandler et forslag af den tyske doktor Herrmannsen om oprettelse af et frikorps, som han onsker ledet og øvet af rådstuebetjent Lohse. Callisen fandt dog dette for tiden ugørligt. Den anden skrivelse opfordrer magistraten til ved plakater på offentlige pladser $o$. l. hurtigst muligt at publicere alt, hvad der kommer fra den provisoriske regering. I skrivelsen får man et tydeligt indtryk af tidens revolutionsfeber: „Hændelserne udvikler sig nu så hurtigt, at den store mængde ikke behørig bliver underrettet derom . . . Postgangen er endnu for langsom i forhold til tidens bevægelse. Alt dette fremmer hinanden stadig krydsende rygter af den forskelligste slags, hvorved folkemassen foruroliges, som ser begivenhederne udvikle sig, uden at kende deres grund og sammenhæng“. Jacobsen fremhæver, at navnlig i Flensborg, hvor anskuelserne er så delte, gælder det om at underrette befolkningen, særlig de lavere klasser, så hurtigt og sandfærdigt som muligt om, hvad der sker. Navnlig er det ønskeligt at få publiceret ved opslag o. 1. de provisoriske love om pressefrihed $\mathrm{m}$. m. og de forventede, allerede besluttede love om kopskattens afskaffelse og antagelsen i de offentlige kasser af preussiske dalere til 40 sk. hver. Det var jo love, hvoraf man ventede en gunstig virkning på befolkningens stilling til revolutionen.

Af Jacobsens nævnte skrivelser fremgår i hvert fald, at større begejstring i Flensborg for den provisoriske regering har han ikke modt. En uges tid senere (den 4. april) skriver den anden regeringskommissær, Wilh Ahlmann, fra Flensborg til den provisoriske regering efter at have meddelt, at der dagen før viste sig to danske krigsskibe i havnen: „Her og navnlig i byens nordlige dele hersker modløshed, ja selv fjendtlighed, og nødig 
vilde jeg opleve et tilbagetog gennem denne by efter et nederlag. - Denne beboernes stemning kan ikke forblive uden indflydelse på stemningen hos soldaterne, som bearbejdes stærkt af de fjendtligsindede borgere, og hos menige og underofficerer begynder der allerede at opstå lunkenhed“. Ahlmann fremhæver endvidere det skadelige $i$, at tropperne ligger uvirksomme så længe, medens fjenden stadig rykker nærmere.

I en beretning, skrevet dagen efter af Jacobsen i eget og Ahlmanns navn, gentages samme klage: lunkenhed og modløshed tager stadig til blandt tropperne! I øvrigt fortælles om, hvad han og Ahlmann har foretaget sig $\mathrm{m}$. h. t. filialbanken, hvor de næsten tømte kassen for klingende mont mod sedler. Jacobsen betoner $\mathrm{i}$ denne forbindelse det særdeles ønskelige $i$, at banken af hensyn til en stor del af byens købmandsstand fortsætter med sin diskontoforretning. Endvidere omtales, at kontrollør Møller (formentlig toldkontrollør Svend Møller) har taget orlov og endnu ikke afgivet nogen anerkendelseserklæring, hvad han formodentlig heller ikke vil, samt at man fra dansk side ved udsendinge og proklamationer søger - ikke uden resultat at få befolkningen $i$ det nordlige Angel til at skille sig fra slesvig-holstenismen. Vedlagt beretningen er for resten en skrivelse fra nordslesvigeren $H$. A. Krüger til borgerne i Løgumkloster, hvori hver fædrelandssindet mand stævnes til møde $i$ Agerskov den 3. april med våben til hest og til fods!

Dette, kan man sige, var nordslesvigernes svar til „den forenede stænderforsamling“, der samme dag i Rendsborg uden de nordslesvigske deputeredes tilstedeværelse - med 74 stemmer mod 2 besluttede at anerkende den provisoriske regerings andragende om Slesvigs optagelse i det tyske forbund. De 2 nej-stemmer var Flensborgs deputerede, agent Jensen og H. P. Schmidt. De kom først efter forsamlingens åbning, og det er med en vis bevægelse, man læser i referatet: Begge de deputerede for byen Flensborg trådte $i$ dette øjeblik ind $\mathrm{i}$ forsamlingen og indtog deres pladser $\mathrm{i}$ denne. Man spørger sig selv: er 
dette varslet om, at der nu fra Flensborg skal lyde samme djærve protest som den, der med Krüger som talsmand lød på mødet 18. marts. Sådan gik det dog ikke. De to flensborgere kom desværre så tidligt, at de sammen med de andre deputerede rejste sig, da der stilledes forslag om en tak til den provisoriske regering for dens optræden og virksomhed $\left.{ }^{4}\right)$. Der havde hørt mod og karakterfasthed til at blive siddende - ganske vist.

Men da forsamlingen derefter gik over til at drøfte, hvorvidt man skulde billige det skridt, som den provisoriske regering havde taget for at få Slesvig optaget i det tyske forbund, var det forbi med flensborgernes ikke-oppositionelle holdning. Under debatten tog agent Jensen ordet ikke færre end fire gange for indstændig at fraråde dette skridt. Ved afstemningen stemte 74 for at billige det, 2 - flensborgerne - imod.

Agent Jensen betonede, at han stedse havde været en bestemt modstander af Slesvigs tilslutning til det tyske forbund: De bestående forhold var for Slesvig de bedste. I Nord- og også i Mellemslesvig var mange af samme mening. Tyskland var splittet. Det havde ikke noget med frihed at gøre at ville tvinge en del af Slesvig mod dets vilje ind under det tyske forbund. „Det vil jeg ikke, det kan jeg ikke“. „Befolkningen selv vil blive, hvad man er, man vil, at Slesvig forbliver lykkelig i de bestående forhold". Denne udtalelse er en smuk bekræftelse på rigtigheden af det ovenfor anførte motto, som pastor Valentiner i sin stortyske begejstring hånede: „Vi vil forblive, hvad vi er".

I sine senere indlæg udtalte Jensen, at der ikke i nogen af de kongelige proklamationer var udtrykt, at man ville inkorporere Slesvig. Og han protesterede mod' snakken om, at kongen var behersket af den københavnske pøbel: Hvor var beviset herfor?

4) I Flensiburger Wochenblatt 20.9. 1848 bringes der et uddrag netop af disse forhandlinger. Der siges herom: Auf Verlangen eingerückt. Kravet må være kommet fra slesvig-holstensk side, og hensigten er naturligvis at vise, at de flensborgske deputerede har sluttet sig til den provisoriske regering. 
Kongen var for tiden i Kolding. „Måske beherskes han af ministerier, men af pobel lader han sig ikke regere". Han fremhævede igen Tysklands splittethed, rivaliteten mellem Østrig og Preussen, mente, at Tyskland snart vilde gå til grunde, og at man måtte søge et andet støttepunkt: de bestående forhold!

Skønt de to flensborgere var de eneste nej-stemmer, kan der være grund til at nævne, at også advokat Chr. Rønnenkamp, der var bosat i Flensborg, men valgt i 9. landdistrikt (valgsted Flensborg), havde udtalt tvivl m. h. t. optagelsen i det tyske forbund. Dels havde han gjort opmærksom på de nordslesvigske deputeredes fraværelse, og dels havde han bemærket: „Jeg kan ikke sige, at der i mit valgdistrikt består en bestemt uvilje derimod, dog er man i almindelighed heller ikke derfor".

Ved behandlingen af forskellige sager i stænderforsamlingen dagen efter betonede agent Jensen kraftigt, at man ikke her kunde tage endelige beslutninger: der behøves "vor hertugs" billigelse, vi kan ikke beslutte, for princippets skyld. - Hvorvidt referatet af Jensens udtalelser er farvede i slesvig-holstensk retning - jeg tænker bl. a. på udtrykket „vor hertug“ - får stå hen. Man kan jo også meget vel tænke sig, at omgivelserne ikke har undladt at få Jensen til at forme sine udtalelser lidt anderledes, end han ellers vilde have gjort.

Stænderforsamlingen udsatte sine møder næste dag. I dette sidste møde fik de deputerede klar besked om, hvordan kongen og hans regering så på den revolutionære bevægelse. Fræsidenten, Jürgen Bremer, oplæste nemlig dels en skrivelse af 30. marts fra det slesvig-holsten-lauenborgske kancelli gående ud på, at enhver deltager i den revolutionære bevægelse vilde blive draget strengt til ansvar, og dels kongens bekendtgørelse af 29. med dens skarpe fordømmelse af den provisoriske regexing. Præsidenten føjede ganske vist til denne oplæsning en udtalelse om, at heraf fremgik, at kongen foreløbig ikke var $i$ stand til at føre regeringen i hertugdommerne: kongen var 
både ufri og forblændet! Men, såfremt flensborgerne har overværet dette afslutningsmøde, har i hvert fald agent Jensen dog nok tænkt, at i Rendsborg havde han ikke mere at gøre.

Nogle få dage efter stod slaget ved Bov, den 9. april, og den eventualitet, Ahlmann havde frygtet, blev virkelighed: slesvigholstenernes tilbagetog gennem Flensborg efter nederlaget. Jeg skal ikke her dvæle ved den militære side, men nævne den begejstring, der navnlig i byens nordlige del slog de danske jenser i møde ved deres indtog. „Overalt vajede Dannebrogsflag, ved alle vinduer viste sig jublende kvinde- og pigeansigter", hedder det $i$ en beretning fra en fangen Kiel-student. Overretsadvokat M. Jäger modtog de indrykkende danske batailloner ved på sin balkon at plante Dannebrog og holde følgende korte tale: „Vor hædrede Danmarks tapre sønner, som tør frejdig slå for kongen og fædrenelandet, skal leve" (fulgt af 3 hurraråb). - H. P. Holst, forfatteren af „Den lille Hornblæser", var med ved de danske troppers indtog og skildrer i en beretning dagen efter den jubel, hvormed de modtoges $i$ byen: „Aldrig i mit liv har jeg set så mange Dannebrogsflag, thi fra hvert andet hus vajede de over gaderne; fra alle vinduer viflede man med tørklæderne; selv småbitte børn svang deres faner og istemte råbet: „Leve de danske! Leve de brave danske!: Det var umuligt at tilbageholde sine tårer".

Men modtoges de indrykkende danske soldater med jubel, fulgte hån og spot de flygtende slesvig-holstenere tii dørs. Det fortaltes senere, at slesvig-holstenerne havde klaget bittert over behandlingen i Flensborg og svoret på, at kom de igen, vilde de ikke lade sten på sten tilbage af byen. De agtede desuden at klynge den dansksindede vært i rådhusvinkælderen, M. H. Kayser, op i lygtepælen foran hans dør, for hvor var de blevet syge efter alt det $ø$ og de stærke drikke, som de havde nydt hos ham! Det kunde aldrig være gået rigtig til hermed. - Mod beretningerne om den overlast, som de flygtende slesvig-holstenere skulde have været udsat for fra flensborgsk side, pro- 
testerede i øvrigt borgmester Callisen i en erklæring af 22. april, få dage før slesvig-holstenernes tilbagekomst. Han stemplede rygterne som usande og hævdede, at borgerskabet havde efterlevet menneskelighedens bud.

Sammen med de flygtende slesvig-holstenere gjorde også nogle af de mest kompromitterede embedsmænd i byen sig usynlige. Forbitrelsen i danske kredse over magistratens „anerkendelse" af den provisoriske regering lod det rygte opstå, at borgmester Callisen ligeledes vilde stikke af, og natten mellem den 8. og 9. holdt et par borgere vagt ved hans hus for eventuelt at hindre dette. Rygtet havde sikkert intet på sig. „Anerkendelsen" havde fra magistratens side været en hensigtsmæssighedsforanstaltning. Den har ikke ment, detté kunde kompromittere den, og den sagde sig løs fra den i samme øjeblik, den danske hær atter var herre i byen.

\section{Det kortvarige danske herredømme (9.-25. april 1848).}

Det slesvig-holstenske nederlag var så afgørende, at den danske hær uden videre kamp kunde rykke syd på og besætte Dannevirkelinjen. Havde den provisoriske regering været henvist til egne hjælpemidler, havde dens dage været talte. Men de tyske magter havde lovet den støtte, og allerede $\mathrm{i}$ månedens begyndelse var preussiske tropper nået til Rendsborg. Tyske forbundstropper fulgte efter. Det var disse langt overlegne styrker, der 14 dage efter Bov-slaget tvang den danske hær til tilbagetog ved slaget påskedag ved Slesvig.

Sammen med eller lige efter det danske militær vendte ogsã enkelte embedsmænd, som ved den slesvig-holstenske besættelse af Flensborg havde forladt byen, tilbage. Dette gælder f. eks. overtoldinspektor Gerth Steenstrup, der 28. marts havde forladt Flensborg og var rejst til København. Den 10. april var han atter $i$ embede. Dagen efter overtog ligeledes postmester v. Holstein sit embede. fra hvilket han var blevet af- 
skediget af den provisoriske regering, med hvilken han ikke vilde have noget at skaffe. Men de allerfleste embedsmænd var, som tidligere sagt, blevet $i$ deres embeder.

Med militærets indrykning fulgte i henhold til krigsminister Tschernings ordre en undersøgelse efter skjulte våben og slesvig-holstenske flygtninge. Her mâtte borgerkorpset bistå, og som stemningen var i byen, er det forståeligt, at det hos forskellige ikke har skortet på iver ved disse undersøgelser. Hos den tyskfødte vært Wilhelm Warnecke, hos hvem den af Jürgen Bremer stiftede Liedertafel holdt sine sammenkomster, fandt der endvidere husundersøgelse sted for at finde Liedertafels fane. Denne var dog blevet gemt hos advokat Boysen og blev ikke fundet, men Warnecke mâtte ud med fanens gyldne spids og gyldne kvast, et bånd, skænket af Würzburgs Liedertafel, samt nodeskabet. Blandt borgerne, der ved denne lejlighed bistod de danske soldater, var advokat Jäger, der søgte at få fat $i$ en vogn for omgående at få „die Liederbücher und die ganze Rebellionsgeschichte" af vejen!

Den dansksindede købmand J. W. H. Jochimsen blev senere, da slesvig-holstenerne igen var herre $i$ byen, anklaget for sammen med Nis Hanssen, der var kommet til Flensborg med det danske militær, at have taget til Husum (midt $i$ april) for at udbrede kongens proklamation af 27. marts. Selv hævdede Jochimsen at have været temmelig passiv ved denne rejse, men formålet med den var klart nok. Det ønske, som Jochimsen fremsatte over for en af dem, de besøgte i Husum, at de tider snart igen måtte komme, hvor man i stedet for krigslarmen byggede jernbaner og havne, er i øvrigt i ægte flensborgsk ånd.

Dagen efter Bov-slaget holdt Frederik VII sit indtog i Flensborg og blev her et par dage. Før sin afrejse lod han den 14. april en deputation fra bykollegierne komme til sig, takkede dem for den venlige modtagelse, som han havde fåt, og forsikrede om at ville gøre byen det gode, han kunde. I spidsen for deputationen, der talte 6 medlemmer -2 fra magistraten, 
4 fra deputeretkollegiet - stod agent Jensen. Når borgmester Callisen ikke var med, skyldtes det formodentlig hans virksomhed for anerkendelsen af den provisoriske regering. Han forklarer selv, at han til krigsminister Tscherning havde sagt, at han måtte holde fast ved sin opfattelse af hertugdømmernes forbindelse. Denne skal derefter have udtalt, at så kunde han ikke være med i deputationen.

Samme dag, som kongen modtog deputationen, fremsattes der fra de to borgmestre og fra deputerede i bykollegiet det forslag, at indlede fọrhandlinger om en fredelig bilæggelse af striden „på basis af den nuværende stilling“. Kongen billigede, at et udvalg fra bykollegierne med Callisen i spidsen foretog en sendefærd til Rendsborg for hos de derværende preussiske autoriteter at fremlægge forslaget. Dette skete om morgenen tidlig den 15. Men general Bonin henviste deputationen til den provisoriske regering, til hvis disposition han var stillet. Deputationen, der ikke havde fået tilladelse til at forhandle med den provisoriske regering, henvendte sig da til denne i en „privat" forhandling og fremhævede ,den usigelige elendighed, som krigen vilde bringe med sig for hertugdømmet Slesvig og byen Flensborg“. Men de provisoriske herrer afviste bestemt byen Flensborgs mægling og $\mathrm{i}$ det hele forhandlinger, for hertugdømmet helt var rømmet, og deputationen fik besked om straks at forføje sig bort fra fæstningen. Den provisoriske regering var også på det tidspunkt sikker på støtte fra Tyskland.

I begyndelsen af april var der blevet udnævnt en dansk provisorisk regeringskommission for hertugdømmet Slesvig. Denne afkrævede den 10. april, dagen efter Bov-slaget, alle embedsmænd en erklæring om deres loyalitet og forhold til den såkaldte provisoriske regering. Kommissionens pågældende skrivelse indeholdt 7 detaillerede spørgsmål, der sigtede til at få nøje rede på embedsmændenes indstilling over for oprørsregeringen. Til Flensborg ankom skrivelsen 13. april, og næsten 
alle besvarelser af de derværende embedsmænd afgaves samme dag.

Magistratsmedlemmerne, der enstemmig havde "anerkendt" den provisoriske regering, gav den forklaring herpå, som vi allerede kender: Man måtte bøje sig for magten, og det var sket for at bevare ro og orden. I øvrigt skinner selvfølgelig de enkelte medlemmers personlige indstilling noget igennem besvarelserne.

En lignende forklaring pả deres "anerkendelse" gav naturligt nok en række af de andre embedsmænd: Havde de ikke bøjet sig, var de blevet afskedigede og brødløse! Blandt præster og lærere fandtes, som nævnt, adskillige slesvig-holstenere, hvad også tydeligt, om end i afdæmpede vendinger, fremgår af besvarelserne. Provst Volquardts udtaler således, at han ogsă fremtidig vil opfylde sin undersåtlige pligt, „således som den påhviler ham i henhold til de bestående love og bestemmelser og særlig i henhold til hertugdømmerne Slesvigs og Holstens stilling til kongeriget Danmark og efter disse hertugdømmers hidtidige indbyrdes forbindelse". Det lyder indviklet, men provstens slesvig-holstenske sindelag er i hvert fald klart. Den provisoriske regering har han anset som et "ordensorgan“, der værnede landet for anarki og vilde overgive det til landets fyrste, når han indfandt sig. Det kan man så tro, om man vil.

Pastor Valentiner, der senere agiterede bravt for slesvigholstenismen, havde ladet den provisoriske regerings bestemmelser publicere i kirken. I begyndelsen havde han, udtaler han, ikke været fuldkommen klar over den provisoriske regerings stilling, men han erkendte, påstår han, meget snart, at det var en ulovlig ovrighed, da den ikke bøjede sig for den kongelige magt, men lige så voldsomt som ubesindigt modsatte sig den. Denne hurtige erkendelse havde slaget ved Bov æren for, men slaget ved Slesvig skulde snart bibringe ham en anden. - Af de andre præster indtog bảde Asschenfeldt ved'St. Nikolaj og Peters, diakon ved St. Marie, en ubetinget loyal 
holdning. Peters kalder den provisoriske regering en bande af landsforrædere!

Af latinskolens lærere var et par taget syd på (til Angel og Holsten) ved skolens lukning, og man kan formode, at deres sympatier var slesvig-holstenske. Hvordan kollaborator Christian Jessens indstilling var, fremgår af, at han under påberåbelse af, at han hverken var statsmand eller retslærd nægtede at svare på de fremsatte spørgsmål. Andetstedsfra vides, at han efter oprørets udbrud anlagde den tyske kokarde, og hans påvirkning af eleverne har nok svaret dertil.

Meddelelser om de ovenfor nævnte tyske troppesamlinger i Rendsborg må tidligt være nåede tii Flensborg og undlod ikke at påvirke stemningen her. "Vi har nu", hedder det $i$ et brev fra Flensborg, skrevet 15. april, „for øieblikket roe, og jeg stoler på Gud og vore gode tropper, men her hersker dog en underlig nedtrykt stemning, da man bestandig frygter, at Preussen pludselig skal falde over os, førend nogen anden hjælp kan komme, derfor ligger også handel og skibsfart endnu næsten stille, og Andr. Christiansen sender sine varer til Kjøbenhavn".

Grosserer Christiansen handlede her som en forudseende mand, thi den $i$ brevet udtalte frygt gik i opfyldelse. Yreussen faldt over os, uden at nogen anden magt var kommet os til hjælp. Slaget ved Slesvig den 23. april tvang den danske hær til tilbagetog. Da vore tropper pâ tilbagetoget gik i kvarter i og omkring Flensborg, opstod her den 24. grundet på falsk alarm panik, og mange afdelinger flygtede hovedkulds nord på. I Flensburger Wochenblatt hedder det herom, at troppernes flugt påskemandag længe vil stá flensborgerne for øje: „Det var skrækkeligt og kunde ikke andet end fremkalde den livligste medfølelse med de allerede så længe og hårdt plagede folk". Hovedparten af hæren trak sig i øvrigt tilbage til Als. Den 25. om morgenen kom de første tyske tropper igen til Flensborg. Denne gang skulde deres ophold blive af adskilligt længere varighed end sidst. 


\section{Det slesvig-holstenske styre indtil vảbenstilstanden 26. august 1848.}

Vender det slesvig-holstenske styre tilbage ved preussernes hjælp, hedder det i det ovennævnte brev fra Flensborg 15. april, „da måtte vi løbe derfra“. Det gjorde også en del flensborgere 1 dagene omkring det danske tilbagetog. Grosserer Andreas Christiansen, der særlig havde været udsat for slesvig-holstenske pøbeloptøjer, bragte sit varelager $\mathrm{m}$. $\mathrm{m}$. til København på den tidligere korvet Diana. Han var villig til at ofre liv og gods for gamle Danmark, og det ridderkors, som han fik i 1850, var velfortjent. I Flensborg konfiskerede slesvig-holstenerne hans ejendom. At advokat Jäger, der havde jublet over de danske soldaters ankomst, foretrak ikke at overvære de tyskes, er også forståeligt. Blandt andre, der forlod byen, kan nævnes bogtrykker Kastrup, udgiveren af „Flensburger Zeitung“, redaktøren af denne, dr. Claus Manicus. og stenhuggermester Klewing. Flere af de flygtede vendte i øvrigt ved våbenstilstanden i august hjem til Flensborg. Dette gjaldt således mægler Struckmann, der 25. april forlod Flensborg for at tage til København, hvortil han i forvejen havde sendt sin kone for ikke at udsætte hende for de farer, som man dengang almindelig regnede med, at den dansksindede befolkning vilde blive udsat for. Hende havde han også givet det løfte selv at følge efter, når tyskerne nærmede sig.

Af magistratens og deputeretkollegiets medlemmer forlod ingen byen ved den nye besættelse. Ingen af dem indtog heller noget ekstremt politisk standpunkt eller havde i de bevægede dage gjort sig særlig bemærket under partikampene. Man havde været fælles først om „anerkendelsen“ af den provisoriske regering og derpå om at anbefale Flensborg til kongens nåde, da h a n drog ind. Den 26. april udnævnte den provisoriske regering nu 2 overordentlige regeringsbefuldmægtigede for hertugdømmet Slesvig, nemlig regeringsråd A. P. A. von Harbou og herredsfoged F. C. F. Jacobsen ${ }^{5}$ ). Af disse indkaldtes 
magistraten til møde på rådhuset den $28 . \mathrm{kl} .10$ for at stå til regnskab for deres handlinger. Til dette møde kunde også de deputerede indfinde sig.

Callisen gjorde her rede for, hvad der var passeret siden revolutionens udbrud, og forklarede, hvordan bykollegiernes eneste bestræbelse var gået ud på at varetage byens bedste under de indtrådte forhold og uden hensyn til politiske anskuelser. Derfor havde man adlydt den til enhver tid herskende magt. Af de ved mødet tilstedeværende magistratsmedlemmer indleveredes $\mathrm{i}$ koncept eller efter hukommelsen skriftligt deres svar på den danske regeringskommissions 7 ovenfor næunte spørgsmål. Af agent Jensens erklæring skal nævnes, at han vedgik, at den provisoriske regering ikke var forekommet ham at hvile på lovlig basis. Hans svar var, udtalte han, bestemt af den overbevisning, at kun kongen kunde løse ham fra hans troskabsed, men at han som magistratsmedlem havde pligt til at sørge for ro og orden i hans fødeby og for dens velfærd.

Få dage efter dette møde afgav Callisen i ovrigt en skriftlig erklæring om bykollegiernes standpunkt og om, hvad man havde foretaget sig. Man havde, betonede han, sat sig den opgave, under hensyn til de flensborgske forhold at holde sig borte fra al politik. Da man fra dansk side efter Bov-slaget havde onsket besked om de deputeredes politiske sindelag, var dette også blevet afvist, og kravet var ikke blevet opretholdt. For sit personlige vedkommende anforte Callisen, at han til krigsminister Tscherning havde sagt, at han måtte fastholde sin opfattelse af hertugdømmernes forbindelse (sml. s. 129).

Denne sidste bemærkning kan nok have stemt de provisoriske herrer gunstigere mod Callisen. Men netop i de samme dage vakte han deres mishag på anden måde. Den 27. april

5) Kommissoriet af $26 / 4$ er trykt bl. a. i Rendsburger Tageblatt, Imidlertid findes i Flensborg byarkiv (911. 1) en skrivelse af 25. april fra Jacobsen til magistraten, hvori han meddeler sit skonstitutorium. af 22. april som overordentlig regeringsbefuldmægtiget. Jacobsen er kommet til Flensborg allerede den 25. 
modtog han fra den provisoriske regering en meddelelse af 19. s. m. om sin udnævnelse til valgdirektør for det 3. valgdistrikt i Slesvig (amterne Flensborg, Sønderborg og Nordborg, byerne Flensborg, Sønderborg og Frøskøbing, Erø, Marstal m. m.) for valg af deputerede til den tyske nationalforsamling i Frankfurt. Herpå svarede han den 28., at forholdene i Flensborg var sådanne, at det efter hans opfattelse for tiden var fuldkommen ugørligt at foretage disse valg. Men den provisoriske regering fastholdt, at han havde at træffe fornødne forholdsregler til, at valgene fandt sted senest 10 . maj. Den føjede til, at den nærede den sikre forventning, at det vilde lykkes Callisens energi at gennemføre dette. Callisen lod derpå den 30 . valgdistriktet inddele i 7 områder med hver sin valgkommissær (6 herredsfogeder samt justitsråd Holm) og gav den provisoriske regering meddelelse herom. Men samtidig stillede han den følgende ubehagelige spørgsmål: Ved valget vil mange sikkert rejse det spørgsmål, om hertugdømmet Slesvig allerede skal anses som hørende til det tyske forbund, eller om dette spørgsmål vil udgøre et emne for den tyske nationalforsamlings forhandling og for en følgende selvstændig beslutning af hertugdommet. Da ønsket om hertugdømmets optagelse i det tyske forbund ikke ${ }^{6}$ ) er rådende $i$ denne egn, er det nødvendigt, at valgkommissærerne kan give vælgerne oplysning herom.

Callisens godt formulerede spørgsmål afslører den provisoriske regerings hele ulovlige færd. Noget juridisk holdbart svar kunde den selvfølgelig ikke give og prøvede heller ikke derpå. Forespørgslen, skrev den tilbage, forklaredes af byen Flensborgs hidtidige okkupation af "fjenden“! Callisen havde selv at skaffe sig underretning om „dette almindelige tyske nationalanliggendes stilling ", men for at lette ham dette sendte regeringen ham nogle numre af Schleswig-holsteinische Zeitung! I ovrigt havde han at adlyde regeringens befalinger,

B) Foran nicht står et durchaus, der imidlertid er overstreget. 
og den ventede af ham, at han i fædrelandsk sindelag med værdighed og cmsorg vilde udføre det vigtige hverv, som var blevet ham overdraget.

Et andet ubehageligt vidnesbyrd om Flensborgs stemning over for revolutionen modtog den provisoriske regering ved et par henvendelser $i$ begyndelsen af maj fra byens handelsforening. Den første, af 1. maj, var en indtrængende henstilling om ikke at ville skride til en beslaglæggelse af danske skibe. Herpå svarede regeringen den 4., at tungtvejende politiske hensyn ikke havde tilstedt at lade Flensborgs kommercielle interesser være de afgørende ved nævnte forordnings udstedelse. Alligevel nærede regeringen den forventning, at Flensborgs handelsstand „vil bære den nuværende tilstands uundgåelige skavanker med et tålmod, der nogenlunde turde svare til den beredvillighed, med hvilken der fra alle dele af landet bliver bragt fædrelandets sag de storste ofre".

Dagen efter handelsforeningens første henvendelse udgik fra den en ny, sendt til den provisoriske gennem magistraten. Man fremsatte her det forslag, at Flensborg blev erklæret for en neutral havn, ligesom det hidtil havde været tilfældet med Lybæk: Vort vel og ve, vor lykke eller ulykke, Flensborgs fortsatte bestån eller undergang vil afhænge af, om den provisoriske regering går ind på forslaget. Krigen havde bragt grænseløs ulykke over byen. - Magistraten anbefalede ved sin fremsendelse af forslaget, at der så vidt gørligt toges hensyn til det. Jeg skal her nævne, at et forslag om Flensborg som neutral by allerede var blevet fremsat af den svensk-norske konsul $i$ byen G. Munck af Rosenschöld et par dage før slaget ved Bov. Han fik af sine foresatte reprimande i den anledning, men bemærkede hertil, at hans forslag blot var en „from önskan, att den (byen) måtte skonas och ett försök att bidraga till partiernas lugnande i staden".

Naturligvis gik den provisoriske regering ikke ind herpá. Vel miskendte den ikke, hedder det $\mathbf{i}$ dens svar, krigens bekla- 
gelige følger for byen, men den måtte alligevel beklage, „når denne by i håb om materielle fordele bestræber sig på at indtage en tvivlsom stilling til landets bevægelse og Danmarks fjendtligheder, en stilling, der turde være egnet til netop at nære falske forudsætninger og håb hos fjenderne og således bidrage til at forlænge krigstilstanden, medens en afgjort åben tilslutning til fædrelandets sag vilde kunne fremme fredens hurtigere komme". Svaret henviste i øvrigt til, at ved fredens afslutning vilde der blive taget hensyn til de byen ved fjendtlig vold tilføjede tab! Denne veksel på fremtiden har de realistiske flensborgske handelsmænd næppe følt større lyst til at diskontere.

Denne i Flensborg fremherskende stemning: frygt for krigen og ulyst til at have noget med "det almindelige tyske nationalanliggende" at skaffe udgør baggrunden for de alvorlige indgreb, som den provisoriske regering først i maj gjorde i byens kommunale selvstyre: udnævnelsen af en overpræsident og af en politisk politimester.

Udnævnelserne fandt sted 6. maj. Til interimistisk overpræsident udnævntes amtmanden over Gottorp amt, baron Fr. N. A. L. v. Liliencron, medens en søn af den gamle general Aug. Krohn, Friedrich Clairant von Krohn, blev konstitueret som politimester ved siden af Niemann. Initiativet til forandringerne i Flensborg blev taget af Bremer. Fra ham foreligger der en længere skrivelse til den overordentlige regeringsfuldmægtige F. C. F. Jacobsen om forholdene, en skrivelse, der er udateret, men efter sit indhold at dømme må ligge forud for udnævnelserne.

Bremer har, hedder det her, for nylig været i Flensborg og er derved desværre blevet bestyrket i den opfattelse, ,at en stor del af den derværende befolkning, af magistrat og deputerede og med dem de fleste mere ansete købmænd, endnu fastholder en sådan indstilling, der ikke blot ikke yder vor sag nogen fremme, men muligvis kan blive farlig for os ved eventu- 
elle fjendtlige operationer mod Flensborg". Det afgjort slesvig-holstenske parti i byen fremstår endnu til en vis grad som det underkuede og kan ikke vinde indflydelse på de offentlige anliggender. I det mindste søger magistrat og deputerede i forbindelse med de mere ansete købmænd at holde det nede. Det gælder derfor om at tage alvorligere forholdsregler i anvendelse imod den flensborgske befolkning.

Bremer foreslår først at fængsle forskellige dansksindede, bl. a. købmand Jochimsen, der har haft den frækhed ikke at forsvinde sammen med de danske tropper! Dernæst mener han, at man skulde tilforordne magistraten en overordentlig regeringsbefuldmægtiget eller sætte ham $i$ spidsen for den, selv om det kunde være vanskeligt at finde en passende mand hertil. .Magistraten bevarer, skriver han, navnlig gælder dette de tre lærde medlemmer, en vaklende holdning, der er uforenelig med vor sag“. Men nævnte tre medlemmer kunde dog for administrationens skyld ikke undværes. Videre ønsker Bremer, at broskriver Christian Hansen straks skal afskediges fra sin stilling, at agent Jensen fjernes fra magistraten, at de tre korps: Christiansgarden, Frederiksgarden og St. Hans Skyttegilde, som i deres helhed har vist sig dansksindede, opløses, og at det samme sker med sikkerhedsvagten, der bør erstattes af en vagt, ledet af afgjorte slesvig-holstenere. Endelig forelægger han udkast til en i „en alvorlig tone" holdt proklamation til flensborgerne, thi de lever stadig i "stor forblændelse".

5. maj anmodede den provisoriske regering Liliencron om dagen efter så tidligt som muligt at indfinde sig til en tjenstlig konference i Rendsborg. Her må altså det nærmere vedrørende hans udnævnelse og beføjelser være blevet aftalt. Udnævnelsen begrundes med, at det af magistratsmedlemmerne $\mathbf{i}$ den sidste tid udviste forhold og hele byens tilstand har gjort ekstraordinære forholdsregler påkrævet. Som overpræsident forsynedes Liliencron med en udførlig instruktion på 12 paragraffer, af hvis indhold følgende skal anføres. Der overdroges 
ham overopsynet med byen og alle dens forhold, og han skulde våge over, at bykollegierne samt alle embeds- og tienestenæænd opfyldte deres pligter mod ,landet. landsregeringen og byen". For at opretholde orden og ro kunde han i nødsfald rekvirere militær bistand. Han var berettiget til at deltage $i$ alle møder, som magistraten holdt enten alene eller sammen med de deputerede, og hans stemme gjorde udslaget, om stemmerne stod lige. Men selv afgørelser, trufne med stemmeflerhed, stod det $\mathrm{i}$ hans magt enten at henvise til fornyet overvejelse eller at indbringe for højere instans, ja i påtrængende tilfælde kunde han provisorisk træffe de efter hans skøn påkrævede forholdsregler. De bestillingsmænd, som det tilkom magistraten at udnævne, skulde approberes af ham, og evt. kunde han kræve andre personer foreslåede. Endelig fastsloges i den sidste paragraf, at han var berettiget til at suspendere embedsmænd og $\mathrm{i}$ stedet interimistisk indsætte andre egnede personer. Det var således særdeles vidtgående beføjelser, der blev den nye overpræsident til del.

Samme dag, som udnævnelsen skete, skrev Jürgen Bremer et længere brev til Liliencron for nærmere at sætte ham ind $\mathbf{i}$ forskellige forhold. Således opregnede han flere flensborgere, der var slesvig-holstensksindede. Først den rige købmand $\mathrm{C}$. D. Birck, om hvem han dog siger, at han er "noget ængstelig“, dernæst besidderen af jernstøberiet i St. Jørgen, Nic. Jepsen, ,en forstandig, helt igennem redelig og åben mand“, men ikke just af udpræget politisk indstilling. Derimod er Walther, ejeren af papirmøllen, både tilforladelig og afgjort slesvig-holstener, skønt "noget forvirret i sin talemåde“. Med god samvittighed har Bremer sikkert kunnet anbefale sin hidtidige skriver, Hansen, til sysselsættelse hos Liliencron.

I brevet udtaler Bremer sig desuden om, hvordan han tænker sig forretningerne fordelt mellem den samme dag konstituerede politimester Friedr. Clairant von Krohn og den hidtidige politimester Niemann. I instruktionen for Krohn er der, skri- 
ver han, herom kun gjort en antydning, idet det overlades Liliencron at træffe de nærmere bestemmelser. Bremer - og den provisoriske regering - mener, at Niemann må kunne fortsætte som rådmand, medlem af fattigkommissionen $\mathrm{m}$. m. m., medens Krohn kun skal have overdraget det politiske politi og sikkerhedspolitiet i snævrere forstand: „Man vil, tror jeg, uden betænkelighed kunne lade Niemann beholde de funktioner, i hvilke der ikke behøves nogen energisk virksomhed for landets ro, og i hvilke der ikke kan befrygtes nogen konflikt med de dansksindede eller de neutrale". Det er en ret ejendommelig, men ganske karakteristisk afgrænsning af en politimesters virksomhedsområde.

I overensstemmelse med Bremers bemærkninger meddelte Liliencron nogle dage senere Niemann og Krohn, at den sidste foreløbig udelukkende skulde tage sig af det politiske politi, navnlig de påkrævede undersøgelser, og af arbejdet med at opretholde orden og sikkerhed. Niemann var meget utilfreds hermed og hævdede overfor den nye overpræsident, at en konstitueret og en virkelig politimester ikke kunne bestå ved siden af hinanden. Men det kom de faktisk til i den følgende tid, selv om forholdet naturligvis medførte en del rivninger. Til den nye politimesters disposition stilledes foreløbig $2-3$ "duelige" individer og specielt den slesvig-holstenske, tidligere omtalte rådstuebetjent Lohse.

Forslaget om en $\mathrm{i}$ "en alvorlig tone" holdt proklamation til flensborgerne realiseredes ved en trykt henvendelse fra den provisoriske regering af 6. maj. Den fremkom først i Schleswig-Holsteinische Zeitung, derefter den 10. maj i Flensburger Wochenblatt, hvorved den kom til den brede flensborgske befolknings kundskab. Det var en temmelig skrap salve. Det konstateres $i$ begyndelsen, at selv om mange indbyggere under den danske besættelse havde holdt fast ved "landets sag“, havde en stor del dog desværre vist sig dels vankelmodig og ubeslutsom, dels fjendtlig mod „den gode sag“. Enkelte havde endda 
gjort sig skyldige i forræderske forbindelser med „fjenden“. Også efter „befrielsen" havde magistraten miskendt sin stilling på så beklagelig en vis, at det havde været nødvendigt at sætte embedsmænd, udstyrede med overordentlig magt, i spidsen for forvaltningen, indtil der var skabt-en bedre tilstand. I proklamationen rettes derpå en alvorlig henstilling til flensborgerne om at opfylde deres statsborgerlige pligter. Enhver forbindelse med fjenden er forbudt og kan straffes med døden. Derı provisoriske regering forventer, navnlig af magistrat og deputerede, „en beslutsom og aktiv medvirken for landets sag (die Lándessache), for hvilken der fra de fleste dele i vort land beredvilligt og med glæde bliver bragt de største ofre fra kommuner og enkeltpersoner og særlig også fra handelsbyer [!]; den forventer, at byens indbyggere ikke ved en smålig og ensidig seen tilbage på en misforstået lokalinteresse lader sig afholde fra at tage del i fremme af det almindelige vel". Regeringen lover til gengæld at befordre handelsinteresserne, også ved den forhåbentlig snarlige fred.

Liliencron havde $\mathrm{i}$ et møde af bykollegierne den 8 . maj præsenteret sig selv som overpræsident og Krohn som konstitueret politimester. I en beretning den følgende dag til regeringen omtaler han, at han har sat sig i forbindelse med borgmester Callisen, men at der først naste dag vil finde magistratsmøde sted. Det kunde ikke ske den 9., da der denne dag var valg til nationalforsamlingen i Frankfurt. Før magistratsmødet lrunde han jo intet sige om, hvorvidt og hvilke medlemmer af den der vilde søge deres afsked. Til ovennævinte proklamation havde allerede en del fået kendskab ved dens fremkomst i Schleswig-Holsteinische Zeitung, og den havde fremkaldt „en temmelig irriteret stemning“. Til slut onitalte Liliencron, hvad der lå af militær i Flensborg: et batteri, en eskadron dragoner og en meklenborgsk gardebataillon. Man burde, mente han, snarere øge end mindske militærets tal og desuden hyp- 
pigt udskifte det, da mange indbyggere prøvede på at demoralisere tropperne.

Om valgene til Frankfurt den 9. forekommer der i Liliencrons beretning den karakteristiske ytring, at der „dog har indfundet sig temmelig mange vælgere". Hans forventning om, at flensborgerne vilde deltage i disse valg, har ikke været stor. Etatsråd Karl Francke valgtes til deputeret for 3. distrikt med henved 900 stemmer, hvoraf en tredjedel skal være kommet fra Flensborg. I en dagbogsoptegnelse af en tysksindet flensborger hedder det: Francke vælges „af fă“. „De fleste indbyggere forholder sig passive". Den svenske konsul i Flensborg, Munck af Rosenschöld, udtaler i en skrivelse til sine regering 17. maj, at der findes 3 partier: et vil tilbage til Danmark, det andet fuldkommen forening med Holsten, det tredje ganske vist forening med Holsten, men ikke at Slesvig skal høre under den tyske forbundsdag. Derfor deltog heller kun 300 i valgene til Frankfurt, uagtet Flensborg havde ca. 3000 valgberettigede.

Dagen efter valget, den 10. maj, gav Liliencron, som han indberetter, magistraten klar besked om dens „beklagelige miskendelse af dens stilling". Underholdningen var, siger han, noget ensidig, da de for største delen tav. Men han mener dog at kunne konstatere, at de ønskede at fortsætte deres virksomhed, hvad også deputeretkollegiet indtrængende nærede ønske om. Han føjer til, at han endnu ikke kan opgive håbet om at vinde Flensborg for „landets sag“, nævner den i byen herskende pengeforlegenhed og fremhæver, at kunde man ved leveringer til hæren tage hensyn også til den flensborgske håndværkerstand, vilde det utvivlsomt gøre et godt indtryk.

Liliencron omtaler endvidere $\mathrm{i}$ denne beretning, at deputeretkollegiet formodentlig vil fremkomme med en henvendelse for at opnå en slags „Ehrenrettung “ for magistraten. I et møde samme aften, hvor 21 deputerede var til stede, besluttedes det også at indgive en sådan henvendelse til den provisoriske regering. Den mundede ud i det onske, at regeringen 
på egnet vis vilde modificere bestemmelsen af 6 . maj om ansættelsen af en overpræsident og suspension af politimester Niemann samt fremfor alt udstede en anderledes beroligende proklamation til byens indbyggere. Dette ses dog ikke at være sket. At de deputerede stærkt har ønsket, at den gamle magistrat fortsatte, er givet.

Nogle få dage senere kommer Liliencron i et par skrivelser til regeringen udførligt ind på de flensborgske tilstande. Den ene omhandler særlig de okonomiske forhold, indkvarteringen, bykassens tilstand og den også hos private rådende mangel på kontante penge, følger af krigen og den standsede handel. „Men en lige så slem fjende șom virkeligheden er den hos mange her rådende modløshed og ængstelighed. Jeg er fuldkommen overtydet om, at megen kapital blot skjuler sig, men jeg ved i det mindste endnu ikke noget råd til at få den frem". Han tilråder bl. a. at hjælpe byens kasse med en mindre sum.

I den anden skrivelse går Liliencron ind på den herskende politiske stemning, som han finder, det vil tage meget lang tid at ændre. „Ved hjælp af den med stor hårdnakkethed udbredte og nærede bekymring for skadelige materielle følger for handel og skibsfart har et talmæssigt ellers ikke meget betydeligt parti mellem de mere ansete indbyggere skaffet sig en meget skadelig indflydelse på den lavere klasse af alle af skibsfarten levende og for skibsbygningen arbejdende hảndværkere og arbejdere tillige med deres familie og omgangskreds („Anhang"). Disse folk, der er lige så uegnede til enhver højere opfattelse af forholdene som utilgængelige for fornuftgrunde, vil ikke blive grundig omvendt fra deres vildfarelse, før freden er tilkæmpet, og det da viser sig, at de nærede bekymringer er ubegrundet. Dertil kommer, at de fædrelandets sag hengivne indbyggere gennem årelang undertrykkelse er gjort helt forknytte (völlig eingeschüchtert), medens det ildesindede parti stadigvæk er meget virksom for fortsat at holde publikum i spænding og frygt ved en utvivlsomt tilsigtet udspredelse af de mest lognagtige rygter". 
For at modvirke sådanne havde Liliencron udstedt en den 10. dateret offentlig bekendtgørelse og henviste desuden til den politiske politimesters bestræbelser i samme retning. Arbejdet med at opspore og aflive - eller i hvert fald straffe — ,rygter", der var ugunstige for oprøret, skulde i den følgende tid skaffe Krohn og hans medhjælpere rigeligt at tage sig til. I bekendtgørelsen hedder det, at det er notorisk, at enkelte slemme flensborgere „søger ved udbredelse af falske rygter og forvanskning af kendsgerninger og forhold at arbejde hen til at fremkalde had mod enkelte personligheder hos deres medborgere, navnlig hos de lavere klasser, at føre byens og omegnens indbyggere vild $\mathrm{m}$. $\mathrm{h}$. t. berettigelsen såvel som styrken af hertugdømmernes sag og at udbrede usande og falske forestillinger om følgerne af en nærmere tilslutning af byen Flensborg til Tyskland". Ganske vist kunde man med tillid imodese „sandhedens og rettens endelige sejr", men alligevel vilde der dog med lovens fulde strenghed blive skredet ind mod sådanne skammelige „Umtriebe"!

Liliencron kunde desuden meddele den provisoriske regering, at han allerede havde indledt „forhandlinger" for at få agent Jensen til at udtræde af magistraten, og at denne selv vilde søge sin afsked. Den 12. maj var Jensen blevet underkastet forhør af Krohn i anledning af forskellige af hans udtalelser, og dagen efter forhørtes han af Liliencron. Liliencron forklarede ham her, at selv om han tidligere havde erklæret at ville adlyde den provisoriske regerings befalinger, måtte han kunne sige sig selv, at ville han ikke være troløs mod sine tit og cffentlig udtalte grundsætninger, kunde han umuligt tjene den provisoriske sådan, som denne måtte kunne kræve det af enhver embedsmand. Jensen erklærede sig derefter også rede til at indgive sin afskedsbegæring. Liliencron tildelte ham en alvorlig advarsel om at afholde sig fra tale og handlinger, der kunde vække utilfredshed, men afstod fra yderligere retslig undersøgelse. I henhold til afskedsbegæringen fik Jensen den 16. maj sin afsked som rådmand af regeringen. 
Om forholdene under den første kortvarige slesvig-holstenske besættelse af Flensborg havde politimester Niemann kunnet fastslå, at ingen af indbyggerne var blevet underkastet politiforhør eller blevet udsat for overlast på grund af politiske anskuelser. Helt modsat formede tilstanden sig nu under den anden, langvarige slesvig-holstenske okkupation og efter Krohns ansættelse som politisk politimester. Straks ved sit komme til Flensborg forefandt han et offer, og talrige angiverier i den følgende tid, bl. a. af en noget misliebig skomager Hans Christian Hansen, leverede ham stadig nyt arbejdsmateriale.

Lørdag den 6. maj havde tommermester Joh. Chr. Rathge og købmand Jochimsen, der begge var blandt de mere fremtrædende dansksindede, gjort sig en glad aften og nok nydt lidt rigeligt af den flensborgske grog. På hjemturen gennem gaderne, hvor det tyske militær færdedes, har de vel været noget frittalende, og Rathge skal have tilladt sig en drastisk udtalelse om, at han sk. . på det tyske forbund og det tyske militær. De tyske soldater, der havde ment at komme som "befriere,“ var, som en af dem udtrykte sig, bitre over flensborgernes „hæslige stemning". Ikke underligt, at Rathge blev arresteret og ført til vagten, hvorfra han næste morgen sendtes til politimester Niemann, der fik ordre til at fængsle og forhøre ham. Dette hverv overtog Krohn nu efter sin tiltrædelse.

Medens Rathge benægtede beskyldningerne, erklærede Jochimsen, at han havde haft en rus og intet kunde huske. Noget fældende vidneudsagn lykkedes det ikke at fremskaffe. Den 19. maj fremsendte Krohn derefter undersøgelsesakterne til den provisoriske regering med en længere skrivelse. Som sagen stod, erklærede han, var der egentlig ikke andet at gøre end snarest at sætte Rathge på fri fod, men dette var ",af politiske grunde“ foreløbig meget utilrådeligt. Begrundelsen herfor var: „Arrestanten hører ikke blot til Flensborg bys afgjort dansksindede befolkning, men udmærker sig blandt denne ved en sand fanatisk danskhed“. Denne har han ikke bare lagt for dagen før kri- 
gens udbrud, men navnlig under den danske okkupation og selv efter danskernes tilbagetog. Tillige besidder han „i kraft af sin personlighed en usædvanlig anseelse hos den lavere klasse i hans næsten udelukkende dansksindede kvarter og har altid gjort sig gældende som ordfører. Lige så ønskeligt som det derfor måtte være på en eller anden måde at indlede en retssag mod ham, og lige så gavnligt som hans i sin tid skete arrestering virkede på den dansksindede befolkning, lige så fordærveligt vilde netop hans frigivelse af fængslet virke under de nuværende ejendommelige forhold i Flensborg". Det var, fortsatte Krohn, ikke regeringen ukendt, at en del af befolkningen stadig havde bevaret en trods og en slet dulgt forbitrelse, som truede med at bryde ud i åben vold ved de første tegn på et omsving $i$ forholdene. At vinde disse folk ,ad fredens og overbevisningens vej" for den tyske sag måtte være fremtiden forbeholdt. Hvad man for øjeblikket skulde tilstræbe, var at bryde det danske partis selvtillid og derved give "det forholdsvis ringe tal af afgjort tysksindede mænd" magt til at drage den store mængde af neutrale og af folk, der vilde se tiden an, over til sig.

Imidlertid vilde dette „kun i ringe grad" kunne opnås ved at indlede retsundersøgelse mod dem, som havde gjort sig skyldige i fjendtlige handlinger mod "die Landessache". Ved en sådan undersøgelse vilde beskyldningerne mod de pågældende nemlig let vise sig som ubegrundede eller ubevislige. „Men på den anden side må man ikke miskende, hvor højst skadeligt det virker, at mænd, som stedse har indtaget en særlig fjendtlig holdning mod die Landessache, og hvis øjeblikkelige retslige fængsling blev almindelig ventet efter Flensborgs besættelse af tyske tropper, endnu går frit omkring og praler af dette overfor ligesindede". Ud fra dette anstiller man betragtninger om den tyske sags svaghed, og den dansksindede befolkning styrkes påny $\mathrm{i}$ dens tro på Danmarks sejr. „Det vil derimod være tilstrækkeligt til helt at knække det danske partis mod og berøve dets modstand sin hovedstøtte, såfremt de af den almindelige opinion („die 
allgemeine Stimme") udpegede parti- og ordførere pludselig fængsles og indtil videre føres bort til et om gørligt ukendt bestemmelsessted“. Krohn indrommede, at en sådan forholdsregel ganske vist kun kunde retfærdiggøres af „den herskende politiske nødvendighed“, men udstraktes den ikke for vidt, vilde den svare til en uomtvistelig, selv om ikke retslig bevislig "skyld" (Verschuldigung) hos de pågældende. Arrestanten Rathge vilde i hvert fald være blandt disse, og Krohn foreslog derfor, at Rathge foreløbig blev deporteret fra Flensborg til et sted, der vilde være at bestemme.

Hvad Krohn her i sin slesvig-holstenske, revolutionære fanatisme foreslår, at altså, at uden lov og dom skulde man fængsle fremtrædende dansksindede og for at give terroren storre virkning deportere dem til ukendt bestemmelsessted! Ganske rart var det $\mathbf{i}$ hvert fald for de pågældende flensborgere, àt det territorium, den provisoriske regering havde opkastet sig til herre over, var af så forholdsvis begrænset omfang, og at det ikke også indbefattede Sibirien.

Overpræsident Liliencron, gennem hvem Krohns forslag blev tilstillet den provisoriske regering, kunde imidlertid ikke helt slutte sig til det. Han fandt, at det at berøve flensborgere deres frihed, „blot fordi de er mistænkte af deres medborgere eller hadet eller frygtet af disse, forekommer mig at være en, selv om også hensigtsmæssig, dog meget betænkelig forholdsregel“. Om det foreliggende tilfælde - tømmermester Rathge, „et her meget berygtet og frygtet menneske“ - bemærkede Liliencron, at af de tre mod ham fremsatte beskyldninger var kun den ene: en drastisk udtalelse om "den tyske frihed" bevist, men næppe strafbar. De to andre kunde for tiden ikke bevises, da vidnerne, nogle soldater, var draget bort. Men han anså det dog for forsvarligt foreløbig at holde Rathge i undersøgelsesarrest. Det vilde rigtignok være godt, om man kunde anbringe ham andensteds end i Flensborg, men hvordan lod det sig gøre, da en fortsat undersøgelse jo eventuelt måtte finde 
sted i byen. At Liliencron for alvor har tænkt sig undersøgeisen fortsat, er usandsynligt, men han har ment, at en henvisning hertil kunde anvendes som en slags begrundelse for vedblivende at holde Rathge indespærret.

Trods Liliencrons betænkeligheder overfor den politiske politimesters forslag gik den provisoriske regering ved skrivelse af 26. maj blankt ind på dette. Den billigede, at ikke blot Rathge, men også de andre af "die allgemeine Stimme" som partiledere i dansk interesse udpegede individer foreløbig fjernedes fra Flensborg, transporteredes til Rendsborg og her afleveredes til politiet. Ved udførelsen heraf skulde der udfoldes al mulig forsigtighed og konduite. Et par dage efter blev Rathge derpå afleveret til politiet $i$ Rendsborg. Som det fremgår af et brev fra omkring midten af juni fra politimesteren i Rendsborg, fik denne ved afleveringen overhovedet ingen besked om grunden til, at han havde at modtage den nye arrestant. En begrundelse var heller ikke så let at formulere, lettere var det $i$ hvert fald at tie.

Men det så godt begyndte værk ventede på fortsættelsen, ventede på, at "den almindelige stemme" skulde udpege de flensborgere, der havde at gøre Rathge selskab. Mærkeligt nok varede det en 3 ugers tid, før Krohn skred til at optage de vidneudsagn, der blev grundlaget for fængslingen den 29. juni af 5 fremtrædende flensborgere, hvoraf dog kun de 4 deporteredes til Rendsborg. Udsagnene fremskaffedes fra $i$ alt 16 indbyggere, der efter Krohns påstand var uberygtede og af anerkendt retskaffenhed. Det får være, hvad det vil, men fra Krohns standpunkt set fortjener måske nok deres tysksindethed og villighed til at tjene som redskaber ved deres medborgeres fængsling anerkendelse. Nogle af dem stammede fra Holsten eller Tyskland. Disse 16 udgjcrde "den almindelige opinion“ (die allgemeine Stimme).

Læser man disse vidneudsagn igennem, slår det én, i hvor høj grad bestemte kendsgerninger savnes. Sådanne behøvede 
Erohn heller ikke. Det var til hans brug nok med almindelige udsagn om, at de pågældende var ansete som særlig dansksindede. De 5, der fængsledes, var købmand Paul Hansen, broskriver Christian Hansen, også kaldet jernbane-Hansen på grund af hans før omtalte interesse for projektet om en tværbane Flensborg-Husum, hjulmager Kruse, værten fra rådhusvinkælderen M. H. Kayser, der for øvrigt stammede fra Bremen og havde været underofficer ved det oldenborgske infanteriregiment, samt Hans Hansen Meng, født i Haderslev, som var fuldmægtig i bysekretariatet i Flensborg.

Om Paul Hansen udtaler et af vidnerne, at han skal have sagt til flere Angelbønder, som var tilsagt til kørsler, at de var tåber, når de adlød den provisoriske regerings befalinger. Desuden skal han tale meget $i$ dansk retning i Borgerforeningen, „i hvilken forening overhovedet anførerne for det danske parti i den grad førte det store ord og daglig gav luft for deres sindelag, at det for tysksindede næppe var til at udholde længere at færdes i dette selskab“. Nå, de tysksindede måtte, synes man, kunne trøste sig ved, at de jo havde deres egen forening: Casino, men menneskene er nu engang ikke særlig lette at stille tilfreds.

M. H. Kayser har vi tidligere hørt om på grund af den andel, som det blev påstået, han havde $i$ de slesvig-holstenske soldaters dårligdom under Bov-slaget. Han lader "sikkerlig", hedder det $\mathrm{i}$ et udsagn, ingen lejlighed gå fra sig til at skade den tyske sag, når han kan gøre det uden fare, thi han er meget forsigtig! Han læser, siger et andet vidne, højt for sine gæster ḋe artikler i aviscrne, der angår den slesvig-holstenske sag, og lnytter altid hertil hånende og spottende bemærkninger om den tyske sag. De tysksindede undgår derfor efterhånden at komme i hans lokale, og kommer en enkelt der endnu, tør vedkommende ikke vove at give udtryk for sit sindelag overfor andre. Heller ikke her var den trøst åbenbart tilstrækkelig for de tysksindede, at der fandtes talrige andre beværtninger $i$ Flensborg end Kaysers. 
Hans Hansen Meng skal både i Borgerforeningen og på gaden, overalt hvor man kommer i snak med ham, skælde ud på den provisoriske regering og søge at fremkalde utilfredshed med dens bestemmelser. Og Christian Hansen og Kruse er kendte nok som førere for dansksindede småfolk, de kan træffes $i$ en kreds af sådanne og talende ivrigt til dem. Kruse er ikke blot fanatisk dansksindet, udtaler et af vidnerne, men virker, hvad der er den ganske by bekendt, for den danske sag, hvor han kan. Da magistraten „erklærede sig“ for den provisoriske regering, skældte han voldsomt ud - det passerede i rådhusvinkælderen - og larmede sådan op, at andre måtte påbyde ham at forholde sig rolig.

Fængslingen af de nævnte 5 flensborgere skete som sagt den 29. juni. Der hersker, skrev Liliencron samme dag til den provisoriske regering, stor ophidselse $\mathrm{i}$ byen $\mathrm{i}$ den anledning, og han havde haft besøg af en deputation, som havde onsket de fængslede frigivne mod at stille kaution for deres forbliven på stedet. Dette havde han afvist. „De ildesindede skal nu have til hensigt $i$ aften at rotte sig sammen for på voldsom vis at give udtryk for deres vilje, og derfor vil man eventuelt blive nødt til at opretholde ordenen ved militær hjælp“. Der fandt også samme aften opløb sted, men det kom ikke til større uroligheder. Næste morgen transporteredes Kayser, Meng, Christian Hansen og Kruse til Rendsborg. Derimod fik Paul Hansen, hvis hustru var alvorligt syg, på familiens bøn lov til at forblive i fængslet i Flensborg, skent Krohn nærmest holdt på, at han alligevel skulde transporteres væk. Da senere undersøgelser viste, at Paul Hansen var uskyldig $i$ den mod ham rettede klage over at have ophidset bønderne, fandt Krohn, at nu burde han sendes til Rendsborg! Der var ikke læengere noget at undersøge, hvorfor der ingen grund var til hans forbliven $i$ Flensborg. Til trods herfor blev Paul Hansen ikke deporteret. Sidst $\mathrm{i}$ juli blev han løsladt mod at underskrive en erklæring bl. a. om, at han vilde undlade al tale og handlen, der var egnet 
til at vække utilfredshed med den provisoriske og de „til varetagelse af hertugdømmernes rettigheder" trufne foranstaltninger. Det tilkendegaves ham, at man vilde holde øje med ham, og forbrød han sig mod de givne pålæg, vilde han på ny blive fængslet.

Om de skete arrestationer og påfølgende deportationer siger Liliencron $i$ et brev få dage senere, at om ikke alt skuffer ham, har de virket „meget godt“. En dansksindet købmand kom også samme dag, fængslingen skete, forskrækket til en af politibetjentene og bad denne meddele Krohn, at han aldrig igen vilde udtale sig om politiske sager! Det havde han heller.ikke gjort de sidste 8 dage. Han havde ganske vist ved middagstid (altså den 29.) været blandt de ved rådhuset sammenstimlede, men ikke sagt noget, heller ikke sådan som de andre råbt hurra for Callisen - det var vel at betragte som en demonstration mod Krohn - men han var gået rolig hjem. Han var ikke dansker, men slesviger, han kunde blot ikke slutte sig til slesvig-holstenerne. - Da der senere bliver tale om at lade de deporterede komme hjem, fremhæver Krohn, hvilken overordentlig værdi den trufne forholdsregel havde haft: Det var ikke alene det, at de borttransporterede var hindrede $i$ at virke til skade for die I.andessache, "men det uventede i denne forholdsregel og dens ubestemte betydning har ikke undladt at skræmme den dansksindede befolkning“. Og hvilken virkning havde det ikke haft i den følgende tid bare at true med transport til Rendsborg!

Slet så begejstret for forholdsreglen var politimesteren i Rendsborg ikke. Den 5. juni havde denne ladet optage forhør over Rathge af "formelle grunde" og med risiko for at besværliggøre „opnåelsen af det materielle undersøgelsesformål“, da der manglede enhver basis for forhøret. Rathge var nemlig blevet afleveret til det rendsborgske politi uden nogen "species facti“, udtaler politimesteren; vi andre vilde sige uden begrundelse. At Rathge var dansksindet, har politimesteren jo nok kunnet fatte. Nogen forholdsordre havde politimesteren heller 
ikke fået fra den provisoriske regering. I forhøret erklærede Rathge beskyldningerne mod ham for usande, men indrømmede tidligere at have været kongeligsindet, hvad der imidlertid var hørt $\mathrm{op}$, da overmagten nu var på tyskernes side! Har Rathge virkelig fremsat denne udtalelse, må den forklares ud fra hans onske om at komme hjem til kone, barn og forretning. At han ikke ændrede politisk overbevisning, vil vi se af de senere begivenheder.

Nogen iver efter at få optaget forhør over de fire den 30 . juni deporterede flensborgere viste den provisoriske regering så vist ikke. Forst den 24. juli bestemte den, at der skulde afholdes forhør dagen efter. De fængsledes udtalelser præges naturligt nok i større eller mindre grad af deres længsel efter at komme hjem til koner, børn og virksomhed. De har sikkert ikke anset det formålstjenligt for dette ønske at fremhæve, hvad de måtte have virket $\mathrm{i}$ den danske sags interesse.

Således erklærer Kayser, at han ganske vist ingen sinde har lagt skjul på sit danske sindelag, men han har aldrig virket $\mathbf{i}$ denne retning. Han onsker at komme hjem og vil i så fald afholde sig fra al politik. Meng benægter forskellige ham tillagte tyskfjendtlige udtalelser, vedgår, at han aldrig har stukket sit danske sindelag under stolen, men han har aldrig $i$ handling bevist det („nie bethätigt,). Hans kone er svagelig, de har 3 børn, og han ønsker at komme hjem. Et indtrængende ønske herom nærer også broskriver Christian Hansen, der tilbyder så eventuelt at lade sig pålægge husarrest. Han er af sindelag slesviger, specielt flensborger, men det er alt for stor en ære at anse ham for hovedfører for de dansksindede og tillægge ham indflydelse på disse. At enkelte personer undertiden kan have samlet sig om ham for at drøfte dagens hændelser med ham, vil han ikke nægte.

Kruse vil selvfølgelig også helst hjem. Han anfører, at siden „anerkendelsen“ af den provisoriske regering har han ikke en eneste gang været på værtshus og ikke agiteret for sine an- 
skuelser. I øvrigt spores tydeligt gennem forhørsreferatet hans djærve, fyndige røst. „Han er ikke slesvig-holstensksindet og siger sin mening lige ud". Han har opponeret ivrigt mod Flensborg magistrats anerkendelse af den provisoriske regering; „denne ret har han haft som borger, thi folket behøver intet formynderskab lige over for fyrsten“.

Få dage efter det optagne forhør sendte den provisoriske regering det til Liliencron og udbad sig en erklæring om, hvorvidt særlige grunde talte imod at gå ind på den af Rendsborg politi foreslåede og af de deporterede selv indstændig ønskede transportering til deres hjemsted. Kunde man ikke nøjes med, når fangerne atter var afleverede til Flensborg politi og løsladte, så at stille dem under polititilsyn?

Så surt et æble kunde Krohn ikke fortære på engang. I sin erklæring først $i$ august udtaler han, at da han affattede sin skrivelse 19. maj, gik han ud fra, at Slesvigs statsretlige forhold i løbet af nogle uger vilde være $i$ den grad stabiliseret, så man kunde se bort fra "denne ligesom fra mangen anden overordentlig forholdsregel“. Dette var jo nu ikke sket, men kunde den trufne forholdsregel erstattes med en lige så god? At løslade samtlige fanger vilde sikkert have en meget uheldig virkning, lokaløvrighedens autoritet vilde svækkes og de dansksindedes mod i høj grad stige. Han foreslog derfor, at man nøjedes med at transportere Christian Hansen og Kayser tilbage til Flensborg og frigav dem på nærmere af politiet fastsatte betingelser. De tre andre vilde han ikke have hjem, men måske kunde de interneres $i$ en eller anden mindre holstensk by.

Liliencron, som anbefalede Krohns forslag, bemærkede, at forholdsreglen hovedsagelig havde sigtet til at bryde det herværende dansksindede partis "frække trods" ved at skabe frygt for en lignende skæbne. Dette formål var nået. Men løslade dem alle var for meget. Nogle af dem var også i den grad frygtede $i$ Flensborg, at alene deres tilstedeværelse der vilde gøre et temmeligt nedslående indtryk på forskellige. - Den provisoriske 
regering fulgte Krohns forslag, hvorpå Christian Hansen og Kayser frigaves mod løfte om at afholde sig fra enhver virksomhed $i$ dansk retning. Med diligencen ankom de den 14 . august atter til Flensborg og meldte sig hos politiet for at få besked om, hvordan de fremtidig havde at forholde sig.

Den 26. august sluttedes der i Malmø en 7-måneders våbenstilstand mellem Danmark og Preussen på Tysklands vegne. En af bestemmelserne $i$ denne overenskomst gik ud på, at alle krigs- og politiske fanger skulde fra begge sider frigives uden ophør eller forbehold. Der var således al anledning til at få afviklet den ekstraordinære foranstaltning med deportationerne. Jürgen Bremer spurgte også $i$ et brev af 28. august Krohn, om de tre endnu fængslede flensborgere ikke kunde løslades på visse nærmere betingelser. Krohn svarede for så vidt imødekommende herpå, idet han erkendte, at der måtte ske en forandring i de fængsledes stilling, „da det bedst egnede tidspunkt for deres frigivelse, landets fuldstændige befrielse, synes at være rykket ud i en for fjern fremtid“. Den 8. september fik Hans Hansen Meng besked om at vende tilbage til Flensborg og der melde sig hos Krohn for af ham at få betingelserne at vide for hans ophold der. Og endelig den 21. sept. kunde den først deporterede, den "meget berygtede og frygtede" Rathge, vende hjem til Flensborg, hvor hans blotte tilsynekomst vel allerede har virket nedslående på nogle af de slesvig-holstenere, aer havde haft en finger med i spillet ved hans deportation. Rathge var den sidst losladte, idet hjulmager Kruse allerede tidligere (omkr. 10. sept.) undveg fra arresten og over Flensborg begav sig til Sønderborg, hvorfra han drog til København for aktivt at give udtryk for sit danske sindelag.

Ved omtalen af, hvorledes de sidste af de deporterede flensborgere slap bort fra Rendsborg, er vi gået lidt ud over den tidsgrænse, som er sat for dette kapitel. Vi vender os igen til tiden kort efter de nye slesvig-holstenske autoriteters indsæt- 
telse for at fortælle om en række andre udslag af disses kamp mod de dansksindedes "frække trods" - eller om divergenser med bystyret, selv om dette principielt var villigt til at føje sig efter magthaverne. Først skal dog nævnes en længere beretning fra slutningen af maj, i hvilken overpræsident Liliencron overfor den provisoriske regering gav udtryk for sit syn på de flensborgske forhold.

Liliencron og Krohn havde, da beretningen indsendtes, virket to-tre uger, men Liliencron mente ikke at kunne konstatere nogen væsentlig forandring i forholdene. Nok var det lykkedes at gøre nogle personer, der tidligere drev deres uvæsen temmelig åbent, mere stille og forsigtige, men mon de ikke alligevel hemmeligt vedligeholdt og søgte at fremme et overfor "die Landessache" fjendtligt sindelag? Herpå tydede de stadig opdukkende rygter om forventede angreb af danskerne. Hos de "velsindede" savnede man stadig, at de ikke afgjort trådte i brechen for deres overbevisning, og der rådede hos det store flertal en beklagelig ængstelighed og halvhed. „Flertallet af de højere stående indbyggere hører til de handlendes og fabrikanternes stand, og denne har, ganske vist med mange så meget mere ærefulde undtagelser, $i$ den grad vendt alle sine følelser mod de materielle interesser og lader sig i så høj grad beherske af de ydre forholds tryk, at ingen anden følelse kan måle sig dermed (dagegen aufkommen); næsten almindeligt råder en stor modløshed, og de flestes eneste hjertensønske er fred, fred for enhver pris".

Det siger sig selv, fortsatte Liliencron, at såfremt det overhovedet er muligt at ændre et så småligt sindelag, der er blottet for ethvert højere sving, vil det dog ikke kunne ske let og hurtigt. Det stadige omkvæd lyder, at handelsforbindelserne med Danmark nu engang er ødelagte, og at de ikke vil kunne knyttes igen på samme vis. Heroverfor nytter det ikke at henvise til, at det ikke er nationale sympatier, men gensidigt behov, som betinger handelen, eller at pege på en eventuel fortsættelse af 
personalunionen. Nye handelsforbindelser tiltror flensborgerne sig ikke at kunne opdyrke. - Noget forbedret mod forhen var alligevel stemningen efter manges mening, anførte Liliencron. Således var en koncert bleven ret talrigt besøgt, som de i Flensborg garnisonerede brunsvigere havde givet i Marieskoven. Tilhørerne vovede endog at applaudere, da musikken spillede „Schleswig-Holstein . . .“. Handelen var også tiltaget noget. Den i det hele dog temmelig pessimistiske beretning endte Liliencron med det hjertesuk, at en overpræsident, der boede til leje i nogle værelser, som de nu engang var til at få, og uden familie og uden egen husholdning ikke hos flensborgerne kunde skabe det ønskelige indtryk af soliditet. - Krohn havde i øvrigt heller ikke sin familie hos sig i Flensborg.

Straks fra sin tiltrædelse som politisk politimester fik Krohn hænderne fulde med sager, der hørte under hans virkeområde, og han var besjælet af iver efter at få det mest mulige ud af dem. Det kom heller ikke til at skorte på angiverier, thi, som en af angiverne skrev til Krohn: skønt fjende af angiveri blev ens tyske gemyt dog tit alt for indigneret over danske propagandamageres virksomhed! Som flittig angiver er allerede ovenfor anført skomager Hans Christian Hansen. En række af sagerne endte med, at de pågældende flensborgere sattes under polititilsyn, og at de morgen og aften, eventuelt også middag, måtte melde sig på politikontoret. Det kaldte flensborgerne at „gå til appel". Blandt de forste, hvem dette blev pålagt, var købmand Jochimsen, der midt i maj måtte møde til forhør vedrørende sin og Nis Hanssens rejse til Husum efter de danske troppers indtog i april (sml. s. 128).

En af byens mere fremtrædende tysksindede var oliemøller Nane Jürgensen. Om ham gik det rygte, at han skulde have nedsat sine arbejderes dagløn og desuden ytret, at sả snart tyskerne havde sejret, skulde alle arbejderes dagløn $i$ det hele taget nedsættes til 8 sk.! Rygtet var velegnet til at styrke den dansksindede arbejderbefolkning i dens sindelag. Jürgensen 
klagede til Krohn, men forhørene førte ikke pả sporet af ophavsmanden. En erklæring om rygtets løgnagtighed lod Jürgensen indrykke i Flensburger Wochenblatt for 13. maj.

Hvor flensborgere af forskelligt sindelag boede i hus sammen, kneb det stundom med fordrageligheden. I den tysksindede købmand Th. Funkes hus boede en købmand Nicolajsen, og dennes i København fødte kommis, der var „meget fanatisk dansksindet", ærgrede tit Funke. Da denne nu en dag - næppe af politiske grunde - gerådede i klammeri med Nicolajsens pige, kom kommisen hende til undsætning. Det endte med, at Funke (omkr. midten af maj) søgte bistand hos den politiske politimester. Kommisen fremlagde under sagen til sit forsvar et brev fra en kollega, hvori det hedder: Det gør mig virkelig meget ondt at høre, at De og Marie således er kommet i klammeri med Funke, men enhver i Flensborg kender ham, så det er slet ingen skam at komme til rådhus med ham! Nå, disse udtalelser står for den pågældendes egen regning. Sagen endte vist iøvrigt $r \in$ sultatløs for Funke.

Rapporteredes det, at man havde kaldt de tyske forbundstropper røvere og spitzbuber, risikerede man selvsagt også at stedes for Krohn. En maler, Johs. Friedr. Schröder, der en maj: aften - måske efter at have nydt et glas grog - stod udenfor sin ved Havretorvet beliggende bolig og politiserede, måtte i kachotten et par dage. Han vedgik at have sagt, at det tyndede ud i de i gaden ophængte slesvig-holstenske faner, og at have hævdet, at han stod under den danske konges værn. Derimod nægtede han at have bebudet russernes, svenskernes og danskernes snarlige ankomst. Det har han såmænd nok gjort alligevel, thi udsigten til hjælp fra svenskerne og russere var den trumf, som de dansksindede spillede ud ved politiske drøftelter og som modtræk til den skete tyske okkupation. En dag sidst i maj fik således skomager $\mathrm{H}$. C. Hansen at vide af en dansksindet, at han hellere måtte pakke sig bort, for snart kom cianskerne og 50.000 svenskere! Hansen ilede til Krohn med „nyheden". 
Det var også sidst i maj, at der opstod slagsmål blandt gæsterne $i$ et af Flensborgs mange værtshuslokaler. Her havde destillateur Petersen, kaldet "engelske" Petersen, der boede i "Norden" (Flensborgs nordlige del), udbredt sig til de øvrige gæster om, at 20.000 russere var på vej for at hjælpe danskerne; yderligere havde kejseren 2 millioner russere! En tysksindet gæst ærgrede sig sådan over "disse uforskammede løgne“, som syntes at finde tiltro hos de andre, at han stemplede Petersens udsagn som løgn. Slagter Patsch bemærkede så, at her havde vi en god konge, og vi vilde ikke vide noget af "det andet skidt" (d. e. de provisoriske). Da tyskerne derpå påstod, at vi aldrig havde haft en konge, kun en hertug, gik Patsch i sin ophidselse over dette til håndgribeligheder. Patsch' forsvar for kongen takseredes af Krohn til en større bøde.

En mere celeber sag fik Krohn at gøre med, da det $i$ første halvdel af august berettedes, at der cirkulerede et smædedigt mod pastor Valentiner ved Mariekirken. Til trods for den loyalitetserklæring, som Valentiner afgav i april (se s. 130), lod han nemlig ret snart under den fornyede slesvig-holstenske besættelse sine tyske sympatier skinne igennem. Da han var præst for en overvejende dansksindet menighed, førte dette lidt efter lidt til et køligt forhold mellem ham og denne. Efter at ærkehertug Johan af Østrig i juni af nationalforsamlingen i Frankfurt var valgt til tysk rigsforstander, blev det bestemt, at der den 6. august skulde finde hyldingsparader sted. Disse begivenheder opflammede Valentiner til åbent at træde $\mathrm{i}$ brechen for den stortyske sag, og i Flensburger Wochenblatt offentliggjorde han artiklen „Politische Bekenntnisse eines Predigers in Flensburg an seine Mitbürger und an die Gemeine". Han dvælede i artiklen ved sin deltagelse 1817 i studenterfesten på Wartburg, ved sit venskab med Uwe Jens Lornsen, ved sin tyskhed og kærlighed til Tyskland: Kærnen af Flensborgs indbyggere er tysk og taler tysk, og derfor skal Flensborg - for øvrigt „naturligvis“ også Nordslesvig - høre til Tyskland. 
Som reaktion mod denne åbne bekendelse må det næunte smædedigt opfattes. I dette blev for at bruge en udtalelse af Valentiner den ed, han havde svoret kongen, „revet ham i næsen". Digtet, hvorom der blev indledet politiundersøgelse 12. aug., har sikkert cirkuleret i mange afskrifter; politiet fik i hvert fald fat i 4 . Forfatteren lykkedes det imidlertid ikke at komme på sporet af - trods Krohns gode vilje.

I digtet hedder det om Valentiner: Du trittst hervor ans Tagelicht - bekennest offen deinen Glauben - nun wird dir auch das Strafgericht - des Volkes jeden Zweifel rauben und zeigen, dass es nie den Mann, - der so denkt wieder achten kann. Lige til nu, siges det $\mathrm{i}$ digtet, havde mange ganske vist hævdet, at Valentiner var en skurk, en ræv i præstekjole, men andre havde stadig troet, at så sort kunde ingen sjæl være eller så vanartet at glemme ed og pligt. Men nu havde Valentiner afsløret sig selv og berømmede sig åbent af at have udsået oprørets frø: „Du Ausbund aus dem Höllenpfuhle“. Mod Valentiners påstand om Slesvigs tilhørighed til Tyskland bemærkede digtet: Dass Schleswig noch vor längerer Zeit - Ein Theil von Jütland ist gewesen - bis in der grausen Vorderzeit - kannst $\mathrm{Du}$ in jeder Chronik lesen — als Syderjütland war's bekannt - Ward später Schleswick erst genannt.

Digtet cirkulerede, som sagt, i flere afskrifter og har nok fået talrige læsere. Hos ejeren af Flensborgs Tivoli, Hohl, fandtes săledes en afskrift. I en angiverskrivelse fra J. C. Hennings til politimesteren omtales to personer, der formentlig vilde kunne give oplysninger i sagen. Den ene, den tysksindede købmand Asmus Schmidt, vil sikkert, hedder det, „med fornøjelse" navngive de personer, hos hvem han har læst det. Anderledes med den anden, oljemøller Claus Andresen, hvis hus Hennings, skønt han ikke er i stand til at give noget bestemt bevis herfor, anser for sæde for mange hemmelige „Umtriebe“. Hos ham skal også den danske præst J. H. Holdt have læst det. Hennings nyttede for resten lejligheden til at rette et angreb 
mod politiets underbetjente, som han påstod alle var „durchweg echt dänisch gesinnt", højst med undtagelse af Asmussen.

I forbindelse med omtalen af smædedigtet mod Valentiner skal nævnes, at den ved St. Marie pigeskole ansatte hjælpelærer Peter Jensen lod forskellige af sine elever afskrive et dansk digt med dansk tendens, som Krohn udtrykker sig. En af pigerne huskede, da hun først $i$ august forhørtes herom, følgende:

\author{
Kong Frederik drog til Striden \\ og blodig Kamp vel ud, \\ sin Hær var nok kun liden, \\ dog Danske have Mod. \\ Høit vifted Dannebrogen \\ i Kampen stolt foran, \\ igjennem Damp og Røgen \\ fast staae de danske Mænd. \\ Ved Flensborg har de seiret, \\ og drage vider frem. \\ Ved Slesvig er de leiret, \\ den By saa falsk og slem.
}

Digtet forekommer noget hjemmegjort. Jensen fandt det klogest at fjerne sig fra Flensborg ved begyndelsen af hundedagsferierne og siges at være gået $i$ dansk krigstjeneste.

Vi har tidligere omtalt, at overpræsident Liliencron kort efter sin tiltrædelse fik agent Jensen til at søge afsked som rădmand (se s. 143). En måneds tid senere søgte også rådmand M. Holst sin afsked. Som grund hertil anfører han senere (i 1850), at han med sin aflagte ed i minde ikke kunde forsvare at tjene den såkaldte provisoriske regering. Liliencron anbefalede den provisoriske regering at give Holst afsked. Holst var, udtalte han, „en ægte flensborger": politisk var han mildest talt indifferent, og administrativt udfoldede han ingen særlig virksomhed. Om man i den pågældende bydel kunde finde en tedre rådmand, var måske uvist, men sikkert vilde man ikke tabe ved et skifte, og et afslag til Holst vilde ikke være egnet 
til at hidføre en fremtidig gavnligere virksomhed fra ham. Den 24. juni fik Holst derefter sin afsked.

En måneds tid senere holdtes der af bykollegierne valg for at besætte de to rådmandspladser for Marie sogn, der var ledige ved Jensens og Holsts afsked. Valgte blev købmændene H. Henningsen og Claus Schwennsen med henholdsvis 12 og 11 stemmer. Da Liliencron $i$ begyndelsen af august indberettede resultatet, udtrykte han sin store tilfredshed med valget af Henningsen. Han er, udtalte Liliencron, „en erfaren, virksom, tysksindet og $i$ enhver henseende agtværdig mand“; særlig energisk fandt han ham dog ikke. Mindre tilfreds var han med den dansksindede Claus Schwennsens valg. Han betegnede ganske vist Schwennsen som dygtig og forstandig, men „efter sit politiske sindelag hører han til klassen af dem, som i denne henseende lader sig bestemme mere ved deres virkelige eller formentlige fordel, og hans forbindelser med filialbanken har derfor hidtil fort ham over på dansk side“. Dog var han ikke trådt særlig frem blandt de dansksindede, og hans adfærd, mente Liliencron, havde ikke været af en sådan art, at det var betænkeligt at billige valget. Man havde desuden aldeles ingen sikkerhed for, at et nyt valg vilde give et "bedre" udfald.

I forbindelse med disse forandringer i magistraten skal nævnes, at under den nye slesvig-holstenske besættelse tog forskellige embedsmænd i Flensborg deres afsked eller afskedigedes, fordi de ikke anerkendte den provisoriske regering. Til de flensborgske embedsmænd kan man ganske vist ikke bogstavelig henregne amtmanden over Flensborg amt, kammerherre Carl Ludwig von Warnstedt, men amtshuset lå dog i umiddelbar nærhed af byen. Ved oprørets udbrud havde Warnstedt anerkendt den provisoriske regering og begik, som han senere udtalte, mange ulovlige handlinger. Men efter Bov-slaget stillede han sig til den danske regerings disposition. Da slesvig-holstenerne atter var herrer, nedsatte de en kommission til at undersøge hans adfærd, og Warnstedt erklærede nu over for denne, 
at han ikke kunde anerkende den provisoriske regering. Midt i juni fik han så sin afsked og tillige besked om at forlade Flensborg, da man fandt hans nærværelse her skadelig.

Af toldvæsenets personale i Flensborg afskedigedes flere: Først i juni meddeles det således, at kontrollør Møller har opgivet sin stilling, og at toldinspektør, kaptajn Oehl og kontrollør, kaptajn Höhling er afskedigede efter ansøgning. Sidst i juni foreslår Liliencron toldassistent Fock afskediget og desuden sendt væk fra byen, da han åbent giver udtryk for sit „bekendte fjendtlige sindelag". Han bør sendes til Rendsborg og først efter nogle uger få lov at begive sig herfra til kongeriget. Da Fock i begyndelsen af juli erfarede, at et ophold i Rendskorg vinkede forude, foretrak han hemmeligt at flygte fra Flensborg og undslap også lykkeligt og vel til Als. Øen Als kom i det hele til at spille en stor rolle som tilflugtssted for kortere eller længere tid - for mange flensborgere.

Det flensborgske bystyres principielle villighed til at adlyde besættelsesmyndighederne blev en god måneds tid efter ckkupationen sat på en hård prøve. Den 2. juni udstedte den provisoriske regering en forordning om optagelse af fortegnelser over det 25-19-årige mandskab, der hidtil havde været fritaget for værnepligt. Regeringen agtede nemlig, meddeltes det i forordningen, at forelægge stænderne, der skulde træde sammen den 14., en lov om almindelig værnepligt og vilde så gerne fremskynde forarbejderne til denne lovs udførelse. I købstæderne pålagdes det borgmesteren at lade optage disse fortegnelser. Han skulde herved bistås af en kommission af bykollegierne, bestående af et medlem af hvert kvarter. Kvartererne inddeltes i lægder; for hvert lægd skulde udnævnes en lægdsmand, som fik ansvaret for lægdslisternes udfærdigelse.

Det var ikke at vente, at denne forordning skulde vække nogen almindelig glæde i Flensborg. Større lyst til at opgive den hidtidige frihed for værnepligt har sikkert ikke rådet $i$ befolkningen, og navnlig har dennes store dansksindede flertal 
ikke næret onske om at blive udskrevet til krigstjeneste mod deres fædreland. Borgmester Callisen gjorde den 10. juni overpræsidenten opmærksom på, at forfærdigelsen af lægdsregistrene vilde berede vanskeligheder. Et valgt kommissionsmedlem havde afvist valget, men der var dog fundet en anden i hans sted. Tre lægdsmænd havde allerede erklæret, at de under ingen omstændigheder vilde overtage dette hverv, og Callisen mente, at navnlig $i$ byens nordlige del vilde flere indtage samme standpunkt. Det forekom ham ugerligt heroverfor at anvende bøder og andre tvangsmidler, og han fandt, at det havde været klogere, om man foreløbig havde udsat forordningen for Flensborgs vedkommende. Han endte dog med at udtale, at nu måtte man se, hvordan man kunne få den gennemført.

Liliencron svarede, at man ikke kunde nægte at overtage hvervet som lægdsmand, og at man burde skride skarpt ind overfor nægtelser. Sagen forelagdes imidlertid den provisoriske regering, hvad der fremkaldte en længere betænkning herom af 22. juni fra Liliencron. Det hedder $i$ denne: „Til den almindelige uvilje mod at se sig underkastet den almindelige værnepligt kommer hos mange herværende indbyggere utvivlsomt også uviljen mod at indtræde i den tyske hær, og jeg tvivler ikke om, at gennemførelsen af den pågældende forholdsregel her vil støde på stor modstand og måske fremkalde en demonstration, der ikke vil være uden betænkelighed". Sandsynligvis må man ved skarpe bødetrusler tvinge de udpegede lægdsmænd og husværterne til at opfylde deres pligter, og de vil formodentlig hellere lade sig idømme bøder end give efter. Formentlig vil de heller ikke betale bøderne, men mă sidde dem af i fængslet. Man må da lade politi, eventuelt militær, medvirke 'for at få listerne lavede. En del militærpligtige vil formodentlig også flygte til Danmark, hvad der skal være sket i Sundeved og i Tønder amt, „hvad der har gjort et for vor sag meget skadeligt indtryk på de tilstedeværende hjælpetropper". Det var, mente Liliencron, at vente, at når værnepligtsloven først var 
blevet behandlet og udstedt, vilde forfærdigelsen af lægdsregistrene støde på mindre modstand, og han fandt ikke en udsættelse til dette tidspunkt særlig betænkelig. Det måtte også indrommes, at Callisen, der skulde have med nævnte arbejde at gøre, havde sin tid meget beslaglagt af mangfoldige andre forretninger og krav, „hvilke han efterkommer med megen god vilje". Det betænkelige, endte Liliencron sin beretning, bestod alene deri, at man foretog en udsættelse specielt for Flensborg af en forholdsregel, som skulde have almindelig gyldighed, og derved gav efter for den mangel på fædrelandskærligt sindelag, der også i denne henseende åbenbarede sig i byen.

Den provisoriske regering tog det hensyn til Callisens andragende, at den fritog ham for at have noget med lægdsvæsenet at gøre. Den overdrog dette arbejde til politimester Krohn med pålæg om at udføre det snarest gørligt. En udsættelse gik den altså ikke ind på. Den 8. juli udkom en provisorisk forordning om indførelse af den almindelige værnepligt, og dagen efter tilskrev regeringen Liliencron, at Krohn skulde fremskynde arbejdet med lægdsrullerne, så de var færdige inden den 24 . At Krohn ikke har haft det for let med dette arbejde, ses bl. a. af en skrivelse fra ham til overpræsidenten, hvori han omtaler, at flertallet af de borgere, som udnævntes til kommissionsmedlemmer og lægdsmænd, havde rejst indvendinger derimod. Han omtalte særlig den deputerede Raffenberg, der som den sande grund til sin vægring havde anført, at han var født i Danmark, hvorfor det stred mod hans følelse at hjælpe med en forholdsregel, der under de rådende forhold ligefrem var rettet mod hans landsmænd. Krohn havde derefter fortalt Raffenberg, at han af den provisoriske regering muligvis kunde vente afsked som deputeret borger. Overfor overpræsidenten anså Krohn det ufornødent nærmere at begrunde, hvor nødvendigt det var så vidt muligt også at få deputeretkollegiet udrenset for dansksindede medlemmer.

Om uviljen i Flensborg mod at underkaste sig den alminde- 
lige værnepligt, navnlig under det slesvig-holstenske styre, vidner ligeledes nogle petitioner, der fra byen indleveredes til stænderforsamlingen, som var blevet indkaldt til den 14. juni. Petitionerne betonede den byrde, som værnepligten vilde være for byerne, og fremsatte onske om, at der i hvert fald ikke udstedtes en lov herom, før hele Slesvig var repræsenteret på landdagen. Med andre ord: ikke før de politiske forhold var ændrede. De flensborgske deputerede havde ikke indfundet sig ved åbningsmødet, men advokat Rønnenkamp havde overrakt petitionerne, dog med en udtalelse om, at han ikke fandt sig foranlediget til at understotte dem.

Fraværelsen af de flensborgske og af de nordslesvigske dansksindede deputerede fremkaldte i mødet den 15. et spørgsmål fra en deputeret, om stedfortræderne ikke skulde indkaldes. Der var, mente han, grund til at tro, at stedfortræderne vilde møde, da "propagandaen" (der menes i dette tilfælde den danske) ikke havde haft samme indflydelse på valget af disse som ved valget af de deputerede. Kommissæren oplyste imidlertid, at alle stedfortræderne var indkaldte, hvor de deputerede manglede, og hvor det var sikkert, at man ikke kunde forvente deres komme; dette gjaldt specielt også Flensborg. Fra denne by kunde man imidlertid kun og muligvis vente den ene stedfortræder, købmand Jochimsen, og han havde endnu ikke vist sig. - Det skulde han heller ikke gøre, forståeligt nok $i$ betragtning af hans hele indstilling.

Dagen før åbningsmødet havde Flensborg deputeretkollegium i øvrigt besluttet at opfordre agent Jensen og kancelliråd Schmidt til at indfinde sig i stænderforsamlingen for i denne at varetage byens interesser. Ingen af dem indfandt sig, som sagt, ved åbningen, men i modet den 20. kom Schmidt til stede efter hidtil at have været forhindret, som der står i mødeprotokollen. I forhandlingerne deltog han imidlertid ikke aktivt, og hvordan han har stemt, kan ikke ses af den trykte sṭændertidende. Schmidts ganske vist lidt sene fremmøde kan siges at stemme 
med, at han var forblevet i magistraten, medens agent Jensen udrensedes.

Som det var at vente, resulterede indførelsen af den almindelige værnepligt $i$, at mange flensborgere unddrog sig tjeneste i den slesvig-holstenske hær ved at flygte til Danmark. For Krohn blev der i de følgende måneder ikke få desertorsager at tage stilling til, og vi skal senere omtale nogle af disse. Men omkring den tid, da værnepligtsloven udkom, var fjendtlighederne mellem Tyskland og Danmark ved at afleses. af våbenstilstand. Den 2. juli sluttedes der i Malmø mellem Preussen og Danmark en overenskomst om en 3 måneders våbenhvile og indsættelse af en "fællesregering " $i$ hertugdømmerne. Overenskomsten vakte stor harme hos slesvig-holstenerne og i Tyskland, og den blev heller ikke fort ud i livet. Men i august optoges i Malmø nye forhandlinger mellem Preussen og Danmark, der forte til konventionen af 26 . august om en 7 måneders våbenstilstand og om en „fællesregering“ med Carl Moltke som præsident. Hvorledes det gik med udforelsen af denne overenskomst, skal vi se i næste kapitel.

\section{Fra våbenstilstanden 26. august 1848 til fællesregeringens}

\section{tiltrædelse 22. oktober s. å.}

Malmøkonventionen af 26. august fremkaldte ikke ringe lettelse hos de dansksindede flensborgere. Dels hørte fjendtlighederne op, og dels var bestemmelserne om en fællesregering med Carl Moltke i spidsen gunstige for Danmark. Men konventionen vakte så stor forbitrelse hos slesvig-holstenerne og i nationalforsamlingen i Frankfurt, og den fik så utilstrækkelig støtte fra Preussen, at det ikke lykkedes at gennemføre den efter dens ånd og ordlyd. Den provisoriske regering beholdt næsten et par måneder endnu magten i hertugdømmerne, og da den să aflestes af en ny myndighed, blev dette en „fællesregering“ 
uden Carl Moltke, en regering, som nærmest fortsatte $\mathbf{i}$ oprørsregeringens spor.

Jürgen Bremer, der jo var medlem af den provisoriske regering, sendte to dage efter Malmøkonventionen et længere brev til politimester Krohn, i hvilket han bl. a., som før nævnt, berørte spørgsmålet om at give de flensborgere fri, der endnu sad fængslede i Rendsborg. Dette var også nødvendigt ifølge konventionens bestemmelser. Men brevet giver i øvrigt udtryk for, at Bremer mente, at det slesvig-holstenske politiregimente $\mathbf{i}$ Flensborg skulde fortsætte efter konventionen. Han opfordrede sáledes Krohn til at forhøre mægler Struckmann, der efter et ophold i Danmark nu var vendt hjem til Flensborg, og enten sætte ham under polititilsyn eller sende ham tilbage til Danmark: „Ganske vist er Struckmann vel ikke nogen farlig person, men hans bortdragen og hans ophold i Danmark gør ham i det mindste mistænkelig“.

Men skulde politiregimentet fortsætte, var det mere onskeligt end nogensinde at have et velegnet politipersonale. Bremer spurgte derfor i brevet: „Er det ikke nødvendigt at foretage en forandring med det lavere politipersonale? Egentlig har De vel ikke et eneste menneske, på hvilket De kan stole? Der burde dog være et par politibetjente, hvis sindelag var tilforladeligt". Bremer endte $i$ ovrigt med en beklagelse af, at Krohn måtte være borte fra sin familie - han havde lige fået et barn -, men han måtte indse, at han var uundværlig i Flensborg.

Som svar på disse sprrgsmål oplyste Krohn, at han havde en overpolitibetjent og 6 politibetjente. Af disse sidste var kun 2 nogenledes brugbare, og alle var dansksindede, bortset fra politibetjent Lorentzen, som han derfor udelukkende anvendte. Ganske vist havde han allerede i maj fået bemyndigelse til at antage 2-3 personer til hjælp, men det havde han hidtil ikke gjort, da et par af indbyggerne havde vist sig villige til at forsyne ham med "efterretninger om herværende tilstande (altså udøve angiveri) ... og jeg på denne måde kunde tjene mine 
formål bedre end ved anvendelse af personer, der åbent stod i min tjeneste". $\mathrm{Da}$ han nu imidlertid af Bremers skrivelse forstod, at man også efter våbenstilstandens afslutning vilde lade ham fungere i Flensborg, måtte han anse det for onskeligt: at gøre brug af den omtalte bemyndigelse, idet han formentlig vilde komme til at virke under langt vanskeligere forhold. Han måtte, vedblev han, betragte en fortsættelse af sin funktion som umulig, såfremt der som en følge af våbenstilstandsbetingelserne skulde ske en forandring $i$ regeringsprincipperne. Men han hengav sig med så meget storre tillid til det håb, at regeringen også under våbenstilstanden vilde være frit stillet ved ordningen af landets indre anliggender, idet ,indsættelsen af en neutral regering næsten vilde være ensbetydende med en afvæbning af landet" og syntes uforenelig med en virksomhed af embedsmændene, der gik ud på indre „styrkelse af vor stat på den måde, som det hidtil blev tilstræbt af mig“. Denne virksomhed bestod jo $i$ at holde danske sympatier og dansk propaganda nede, og dette vilde i Flensborg under våbenstilstanden kræve storre midler end hidtil.

Som Krohn her antyder, gjorde han brug af den ham givne bemyndigelse, og $\mathrm{i}$ sept. fik han antaget et par politibetjente yderligere. Ved antagelsen søgte han råd hos sin fader, generalmajor Krohn, og en garanti for skikketheden til hvervet hos dem, der blev antaget, har man jo nok fundet deri, at de pågældende (Mützel og Isensee) stammede sydfra. Men mer' vil have mer'. Efter at have fået politibetjentene onskede Krohn også en 20-24 soldater til Flensborg som gendarmeri. Ved hjælp af sådanne, fremhævede han, vilde det være muligt at overvåge og holde i tømme „Flensborgs dansksindede befolkning i dens uáfbrudte angreb på tilhængerne af "die Landessache“, i dens trods" mod landsregeringens anseelse og bestemmelser". Man kunde også overvåge fremmedbesøget, og korpset kunde bruges i nærliggende landdistrikter, hvor befolkningens stemning var 
ugunstig overfor "die Landessache“. - Krohn måtte dog vente et stykke tid, før han fik sit korps.

Kort efter våbenstilstandens afslutning forefaldt i Flensborg forskellige flagepisoder som udtryk for, at de dansksindede troede, at nu var andre tider oprundne. Den 31. august fjernedes således den tyske fane fra rådhuset, men dagen efter blev den atter hængt ud. Borgmester Callisen anfører i en notits til underretning for de andre magistratsmedlemmer, at den skal blive hængende, til "vedkommende myndighed" beordrer den taget ned. I ovrigt meddeler han i notitsen, at det var Wrangel, der ved sin indmarch $i$ april krævede den hængt ud trods hans, Callisens, indvendinger.

I Ole Samsonsgang blev der den 1. sept. hængt en lille dansk fane ud. Politibetjent Lorenzen blev sendt hen for at få den væk, og da konen, gift med en fraværende styrmand, ikke godvilligt vilde udlevere den, blev hun og fanen taget med på politistationen. En storre flagdemonstration forefaldt den 6 . sept., da Dannebrog gik til tops på de $\mathrm{i}$ havnen liggende skibe og blev stukket ud fra mange husvinduer. Fuld af iver efter at virke til "indre styrkelse af vor stat" begav den politiske politimester sig straks til havnen, militær assistance rekvireredes, og Dannebrog blev efterhånden taget ned på alle skibe og bort fra alle vinduer. En enkelt arrestation fandt sted; og i de følgende dage afholdtes der en række politiforhør over „demonstranterne".

Af disse forhør fremgår, at et par flensborgske skippere, der i flere måneder havde ligget med deres skibe i Høruphav på Als, da de den 6. løb ind i Flensborg havn, lod Dannebrog gả til tops, som skik og brug var til søs. De i havnen liggende skibe hilste igen med Dannebrog, og fra mange huse blev flaget stukket $u d$. Den dansksindede deputerede borger, købmand F. $\mathbf{N}$. F'riedrichsen, vedgik i forhøret, at han havde befalet føreren af sit skib at hejse Dannebrog, så snart et „indenlandsk“ skib 
med det danske flag vajende passerede havnebatteriet. Endvidere havde han givet besked om ikke at tage flaget ned igen uden hans udtrykkelige ordre. Det havde han gjort, fordi han med de $i$ byen herskende meningsforskelligheder havde tænkt sig muligheden af, at bekendte af hans endnu uerfarne skibsfører eventuelt vilde opfordre denne til at tage flaget ned. At politiet vilde beordre flaget taget ned, havde han ikke tæenkt på, da han mente sig $i$ sin gode ret. Han havde ikke villet demonstrere, men villet vise de indløbende skibe en høflighed. Denne grund anføres også af flere af de andre skippere og af borgere i byen, der hejste flaget. En 20-årig pige, bosat i Herrenstall, som svang Dannebrog ud af vinduet, påstod forevrigt, at nogle preussere, der gik nede på gaden, havde opfordret hende dertil.

Et par af dem, der havde flaget, skød skylden på en ukendt ung matros, der skulde have sagt, at man skulde flage. Den ene angav endda, at det skulde ske ifølge broskriver Christian Hansens påbud. Det kan man nu dårligt tænke sig, at Christian Hansen har påbudt, men som så mange andre flensborgere har han sikkert med inderlig fryd fra skibsbroen set skibene atter klædte $\mathrm{i}$ de rød-hvide farver. Men farverne skar de tysksindede $\mathrm{i}$ øjnene, og adskillige ophidsede bemærkninger faldt nok fra begge sider om flagningen. At Christian Hansen har forsvaret denne, kan anses for givet, og da han erfarede, at et par tilstedeværende tysksindede havde rapporteret til politimester Krohn, foretrak han at flygte til.Sønderborg for at undgå en skæbne som den, han tidligere havde været ude for. Den 5.,oktober vendte han dog tilbage, efter forud af rådmand Henningsen at have fået at vide, at han, såfremt han var uskyldig, ikke havde noget at frygte, og at han vilde få sin afsked, i fald han ikke vendte hjem. Dagen efter kom han i politiforhør, men slap med pålæg /om at beflitte sig på den strrste forsigtighed $i$ tale og handling, hvad angik landets politiske forhold. 
Dagen efter flagdemonstrationen udstedte Harbou, der midt i august havde afløst Liliencron som overpræsident, en bekendtgerelse om, at det var forbudt at hejse Dannebrog, og at en overtrædelse af dette forbud kunde medføre fængsling og straf. Til trods herfor hejstes en 14 dage senere det danske flag på en i havnen liggende Grønlandsfarer - som hilsen til en anden Grønlandsfarer, der netop løb ind. Resultatet blev en bøde.

Spændingen mellem dansk- og tysksindede forplantedes også til børnene. Den 8. sept. fandt overpræsident Harbou sig foranlediget til at skrive til skolekollegiet om, at en del af skoleungdemmen forulempede flere af de „hertugdømmernes sag hengivne borgere og deres børn". Hidtil var man optrådt mildt mod dette uvæsen, men fremtidig vilde politiet skride alvorligt ind til værn af de „velsindede“, hedder det. Denne advarsel bekendtgjorides også i Wöchenblatt. Da det noget efter kom til slagsmål mellem drenge ved "broen“ — en dreng, der bar en tysk kokarde, fik denne revet af - måtte deltagerne stille på politistationen, og to af "danskerne“ fik en afstraffelse.

Uanset våbenstilstandsoverenskomsten fortsatte den provisoriske regering sit styre. Overenskomsten blev foreløbig heller ikke anerkendt af den tyske centralmagt i Frankfurt. Den 15. august var den landsforsamling, der var blevet valgt for at vedtage en grundlov for den nye slesvig-holstenske stat, trådt sammen, og 4. sept. besluttede den, at den ikke kunde oploses eller udsættes mod dens egen vilje. Nogle få dage senere vedtoges den $i$ demokratisk ånd affattede statsgrundlov (den udstedtes 15. sept.) for hertugdømmerne Slesvig-Holsten. Disse var, hedder det $\mathrm{i}$ artikel 3 , en bestanddel af det tyske statsforbund. Denne artikel var af landsforsamlingen besluttet med 89 mod 6 stemmer, og blandt de sidste kunde man vel formode, at borgmester Callisen har været. De trykte protokoller har imidlertid kun tallene. I begyndelsen af oktober forlagde cien provisoriske regering sit sæde fra Rendsborg til Slesvig. 
Kun 4 dage efter Malmoroverenskomsten havde den provisoriske regering udstedt en bestemmelse om ophævelse af filialbanken i Flensborg, og først i sept. udstedtes en bekendtgørelse om, at værnepligtige slesvig-holstenere i alderen 21-25 år, der befandt sig udenfor hertugdømmerne, havde at melde sig hos de respektive myndigheder for at opfylde deres militærpligt. Medens den preussiske general Wrangel i en skrivelse af 7. sept. til kommandanturen i Flensborg udtaler, at efter overenskomsten er trafikken mellem hertugdømmerne og alle andre lande fri, meddeler overpræsidenten endnu 18. sept. Krohn, at bestemmelserne fra maj 48 om forbud mod samfærdsel med kongeriget Danmark stadig er gældende! Dog kan disse bestemmelser i visse tilfælde lempes noget. Den 22. sept. tillod en békendtgørelse fra den provisoriske regering foreløbig igen samfærdselen med kongeriget, men kort $\mathrm{i}$ forvejen havde også nationalforsamlingen i Frankfurt vedtaget at anerkende overenskomsten, for så vidt den endnu var gennemførlig.

At det ikke lykkedes at etablere den fællesregering med Carl Moltke i spidsen, som var forudsat i Malmøoverenskomsten, skyldtes, som nævnt, slesvig-holstensk modstand og utilstrækkelig preussisk støtte. Da dette slog fejl, udnævnte den danske regering en såkaldt ,immediatkommission til den fælles regering for hertugdommerne Slesvig og Holsten". Denne kommission fik sæde i Sønderborg og bestod af tre medlemmer: Carl Moltke som præsident, biskop over Als og Ærø Jørgen Hansen og amtmand over Haderslev amt, Fr. Johannsen. 18. sept. udstedte den en bekendtgørelse om sin tiltrædelse og søgte ved udsendinge så godt som muligt at få bekendtgørelsen udbredt. Også Krohn fik tilsendt et eksemplar. Men da den ikke havde magt som agt, blev dens virkeområde begrænset til det af dansk militær besatte område. General Bonin, hvem Wrangel havde overdraget kommandoen, udstedte den 22. sept. en bekendtgørelse om, at han ikke anerkendte kommissionen som den påtænkte „fællesregering“. Samme dag offentliggjorde den provisoriske 
regering en protest imod den og sendte endvidere en rundskrivelse til politiøvrighederne om straks at fængsle kommissionens medlemmer, om de viste sig. Dagen efter lod man desuden udgå en bekendtgørelse om det ulovlige i at bruge danske faner og kokarder.

Af Krohn kunde kommissionen ikke vente at se sin proklamation offentliggjort. Men den 22. sept. fandtes den opklæbet på rådhuset, hvad der fremkaldte et større opløb. Filialbankskriver Torm læste flere gange proklamationen op og meget højt. Skændsmål og korporiigheder mellem dansk- og tysksindede fulgte på, da en af de sidste rev plakaten ned. Rådhuskælderens vært, Kayser, skal have kaldt de tysksindede „lutter pak“. Bagefter fandt han det rådeligst at fjerne sig en god måneds tid fra byen. Lige så lidt som Christian Hansen har han været ivrig efter et nyt ophold i Rendsborg fængsel.

Den provisoriske regerings bekendtgørelse imod kommissionen havde for resten ikke stort bedre skæbne. Den blev slået op på gadehjørnerne, men de fleste eksemplarer blev revet.ned eller grisede til. Det lykkedes Krohn at få fat i tre af „misdæderne“ og få dem idømt tre dages fængsel på vand og brød. Den ene var en i St. Jørgen født tjenestepige, der havde smurt skosværte på plakaten. Hendes kæreste var i den danske hær, og derfor var hun imod "den tyske sag“. Den anden, en enke, havde hældt en kedelfuld vand 2 gange over bekendtgørelsen. Hun vilde, hævdede hun, spule snavset fra husmuren, men hendes renlighedssans blev ikke rigtig påskønnet.

Spændingen mellem dansk- og tysksindede gav sig i disse dage mange udslag. I værtshuse, hvor drikkevarerne gjorde folk mere løsmundede, på arbejdspladser, på torve og ved havnen er de forskellige anskuelser stødt sammen, og smædeord som Spitzbuber, landsforrædere, edsbrydere blev de tysksindede til del. En arbejdsmandskone fra "Norden" satte altid ordet tysk foran sine skældsord: Deutscher Spitzbube, deutscher Lump osv., men da hun snakkede dansk, blev ikke alt forstået af dem, 
skældsordene gjaldt. - I Kaysers lokale indfandt en af Krohns spioner, „hemmelig politibetjent“ Mützel, tidligere ved det v. Tannske frikorps, sig om efterm. den 27. sept. Han havde udbytte af besøget, thi destillateur Petersen (engelske Petersen) sad og læste aviser, skældte ud på tyskerne og forsikrede spionen om, at han var en ægte dansker! Petersen unddrog sig politiforhør ag, hvad dermed kunde have fulgt, ved at tage til Sønderborg, misliebige flensborgeres forjættede land.

En større dansk demonstration fandt sted den 10. okt., da et dampskib afgik til København med danske krigsfanger. som havde opholdt sig på flensborgske hospitaler. Der havde samlet sig en større skare tilskuere, som hilste de bortdragende med høje hurraråb og vinken. Blandt tilskuerne var imidlertid også en købmand J. P. Beck med en tysk kokarde, og da han gik derfra, forfulgtes han af en stor folkehob med trusler og hurraråb. Til sidst lykkedes det dog Beck at slippe fra dem. Efter tysksindedes vidnesbyrd bestod mængden overvejende af "pøbel“, mænd, kvinder og børn, og væsentlig folk bosatte i Norden. Vidnerne mente, at politibetjent Sachau, der var med at splitte mængden, og som kendte hvert barn i Norden, måtte kunne navngive demonstranterne. Men Sachau navngav kun to og undskyldte sit ukendskab til demonstranterne med, at gaden havde været "helt sort" af mennesker.

Som nævnt betjente Krohn sig af lønnede spioner, medens nogle af de tysksindede flensborgere nok har foretaget deres angiverier uden betaling. Hvorvidt arbejdsmand J. H. Asmussen, der den 12. okt. foranledigede en dansksindet matros arresteret, hørte til 1. gruppe, får stâ hen, men det forakommer rimeligt. Han var sysselsat ved vejarbejder, som byen havde sat $\mathbf{i}$ gang for at afhjælpe arbejdsløsheden. Disse arbejder lededes af den dansksindede chausseeopsynsmand G. A. Böttcher, der allerede ved de $i$ juni optagne vidneudsagn af ,",die allgemeine Stimme" var udpeget som moden til Rendsborg. Böttcher skulde således have sagt om medlemmerne af den provisoriske rege- 
ring, at de ikke var bedre værd, end at man købte en strikke til at hænge dem alle op i, spitzbuber, som de var. Mod sàdanne beskyldninger forsvaredes han af en af sine medarbejdere, underopsynsmand Peter Nicolaysen, der imidlertid indrømmede, at han mangen gang sagde et uforsigtigt ord. Böttcher selv vedgik overfor Krohn, at han tidligere havde været kongeligsindet. men som sagerne nu stod, havde han taget et andet standpunkt (sich anders entschieden), uden dog nærmere at forklare, hvori dette bestod. Af Krohn fik han (31. jul1) påbud om at vise yderste forsigtighed med politiske udtalelser, men slap altsá for at komme til Rendsborg. Nu i oktober måtte han på ny i folitiforhor $\mathrm{i}$ anledning af arrestationen af den nævnte matros.

Denne, Lorenz Thomas Thorsen, var torsdag morgen den 12. i sin marineuniform og med den blanke marinehat på hovedet kommet ud til vejarbejderne, da de holdt frokost. Blandt arbejderne var nemlig også Thorsens far. Asmussen yppede nu kiv, og Thorsen bekræftede, at han næste dags aften igen vilde til Sønderborg for at overtage sin gamle post på en kanonbåd. Det var hans pligt; han vilde ikke fornægte sit fædreland. Asmussen og Thorsen skældte nu gensidig hinanden ud for landsforrædere, og Asmussen foranledigede Thorsen fængslet. Da dette skete, skal politibetjent Nøbbe $i$ øvrigt have sagt til T'horsen, hvorfor han ikke stiltiende stak af.

Asmussens bedrift bevirkede, at Böttcher afskedigede ham med den begrundelse, at han ikke vilde have politiseren ved arbejdet. $\mathrm{Da}$ en anden arbejder så opfordrede Asmussen til at klage til Krohn, afskedigede Böttcher også denne. I politiforhøret erklærede Böttcher, at Asmussen havde indrømmet forst at have angrebet matrosen, men havde undskyldt sig med, at Krohn havde pålagt ham at spionere. B. havde så spurgt, om han var hemmeligt politi, og da han ikke svarede herpå, havde B. sagt, at så havde han jo ansættelse, og da B. kun måtte ansætte „brødløse“ folk, kunde han allerede af den grund ikke beholde ham. Hvordan Krohn har optaget disse udtalelser, kan 
desværre ikke ses af referatet. - Såvel opsigelsen af Asmussen som af den arbejder, der havde rådet til henvendelsen til Krohn, var, udtalte B., billiget af bygningskommissionen. Begge borgmestre, Niemann og begge „bygherrer" (to af bykollegiets medlemmer havde denne stilling) havde udtrykkelig anvist ham, B., ikke at tåle, at der forhandledes politik under arbejdet. Efter yderligere spergsmål af Krohn forklarede B., at han ikke havde jaget Asmussen bort af politiske grunde, men fordi han forstyrrede roen. B. havde nok tidligere været dansksindet, men havde nu ikke noget at gøre med den danske sag.

Ved et senere forhør hævdede de to bortviste, at Peter Nicolaysen skulde have sagt, at han havde kunnet få Böttcher til Rendsborg, men at han ikke havde villet sige sandheden om ham. Krohn lod så sine to kronvidner konfrontere med Nicolaysen og refererer herom, at Nicolaysen stadig dyngede beskyldninger på dem, talte om skurkestreger og om et komplot for at fjerne Böttcher fra hans stiHing. Krohns opfordringer til at tie stille besvarede han „på impertinent vis og med stigende trods og tvinger undertegnede (Krohn) til at afbryde forhøret, da en politibetjent ikke er til stede“. At Krohn har været voldsom ophidset over ikke at kunne fremtvinge det af ham onskede vidnesbyrd, forstår man. Nicolaysen anfører, da sagen kom for politiretten, hvor han idømmes en bøde, at Krohn har kaldt ham en „verflucht Kerl“ og sagt, at han skulde sidde indespærret til dommedag („bis er schwarz werde"). Hvordan det senere gik Böttcher, vil vi se i det følgende kapitel. Ved den her omtalte sag lykkedes det ikke Krohn at få ram på ham.

Et godt indtryk af, hvordan forholdene i Flensborg virkede på udenforstående, giver en erklæring, som den vagthavende underofficer i borgerforeningshospitalet offentliggjorde i Wochenblatt den 14. okt. Efter de i erklæringen brugte udtryk går jeg ud fra, at den pågældende ikke var fra hertugdømmerne, men fra Tyskland. Han havde hejst en tysk fane på borgerforeningens hus, men til hans store fortørnelse havde borgerfor- 
eningen protesteret og fået den fjernet. Dette er anledningen til, at han i erklæringen skaffer sig luft for sin galde. Hvorfra kommer, spørger han, dette latterlige had, med hvilket de (borgerforeningens medlemmer) forfølger de farver, som man $i$ alle andre dele af hertugdømmerne begejstret ærer? „De er dog også tyske? De taler tysk, ikke sandt? og dog vil de lige overfor hertugdømmernes øvrige beboere være danskere? Uforklarligt. — Så langt som tyskerens ærlige sprog strækker sig, er der sikkert ikke forekommet noget eksempel på større stupiditet end det, som borgerforeningens selskab, der vil være dansk i det tyske Flensborg, frembyder". Derfor skal han også gerne fjerne sit flag fra en bygning, hvor der ikke hersker fællesfølelse (Gemeinsinn), men kun gemenhed (gemeiner Sinn). Udtrykkene viser, hvor gal tyskeren har været i sit hoved.

Den slesvig-holstenske vægring ved at anerkende Malmøoverenskomsten fremkaldte blandt dansksindede flensborgere rygter om en dansk militær indskriden. Danskerne vilde snart komme igen og jage tyskerne væk, hed det. Krohn indberetter selv $i$ et brev fra begyndelsen af november, at noget efter våbenstilstanden bredte det rygte sig i Flensborg, at da de provisoriske ikke vilde holde stilstanden, skulde Slesvig straks okkuperes af Danmark. Den deputerede borger W. H. Jochimsen brød den ham pålagte „byarrest" og tog til Sønderborg, idet han ved bortrejsen udtalte, at han snart vilde vende tilbage sammen med danskerne. Dette følgeskab måtte han dog savne, da han (vel i begyndelsen af novbr.) vendte hjem til Flensborg. Gjorde han sig igen bemærket, ytrede Krohn i nævnte skrivelse, vilde han give ham husarrest og skride ind. Skulde stenhuggermester Klewing vende tilbage, udtalte Krohn samtidig, vilde han stille denne ivrige danskerven under skarpt polititilsyn.

I tilslutning til, hvad ovenfor er næunt om købmand Frie-drichsens deltagelse i "flagdemonstrationen“, skal omtales, at Friedrichsen først i oktober atter måtte stille i politiforhør, 
f(r)di hans skonnert „Die 2 Gebrüder" i Senderborg havde fået det i Flensborg indbrændte slesvig-holstenske våben udskiftet med det gamle stempel „Dansk Eiendom“. Friedrichsen forklarede, at han havde givet skibsføreren ordre til, hvis der endnu lå et dansk krigsskib udenfor havnen, så at løbe ind til Sønderborg, få danske skibspapirer og et dansk stempel. Dette havde han anset for nødvendigt af hensyn til sin ejendoms sikkerhed.

Kort forinden der endelig etableredes en "fællesregering“ i hertugdømmerne - den 22. oktober - afgav Krohn i anledning af et onske fra Frankfurt om at vide besked med politiske foreninger en beretning om, hvordan dette lå i Flensborg. Et og andet heri er ganske oplysende om forholdene i byen. Krohn anfører, at der havde været planer oppe om at stifte en „Bürgerverein" som samlingssted for de tysksindede mod dansk propaganda og for at komme på linje med Tysklands andre byer. Foreløbig havde man set bort fra denne plan på grund af Flensborgs ,individuelle forhold“. Så vidt gørligt forfulgte man dog nævnte mål i den selskabelige, af velhavende bestående forening "Casino", hvis politiske beslutninger tysksindede af de lavere klasser hidtil ubetinget havde sluttet sig til. Medlemmerne var, udtalte Krohn, næsten udelukkende stemte for en ordnet og rolig udvikling af Tysklands politiske forhold og holdt pá tillid og lydighed mod centralmagten og nationalforsamlingens beslutninger. I tiden fra maj til sept. var Casinos medlemstal øget fra 50 til 180, og tilvæksten vilde sikkert fortsætte. Krohn regnede naturligvis her med, at det slesvig-holstenske styre vilde opretholdes trods Malmøoverenskomsten. Som vi skal se, regnede han rigtigt.

\section{Under fællesregeringen (22. oktober 1848-26. marts 1849).}

Da Malmokonventionens bestemmelser om en fællesregering med Carl Moltke i spidsen havde vist sig uigennemforlige, og der heller ikke var udsigt til, at den af Danmark udnævnte „,im- 
mediatkommission" (se ovenfor) vilde kunne gøre sin autoritet gældende i større dele af Slesvig, indledtes sidst i septemiber nye forhandlinger i Berlin mellem Danmark og Preussen. Disse forte omkring midten af oktober til en overenskomst, hvorved Danmark gik med til en ny fællesregering, der udgjordes af mænd, som Preussen i forvejen havde sikret sig vilde blive anerkendt af slesvig-holstenerne. Præsident for denne 5-mandsregering blev grev Th. Reventlow-Jersbeck; de 4 andre medlemmer var landfoged J. H. Boysen, amtmand J. Fr. E. v. Heintze, overappellationsretsråd A. F. W. Preusser og grev Adolph v. Moltke. Denne regering indsattes 22. oktbr. på Gottorp af den tyske rigskommissær Stedtmann og den danske udsending Reedtz. Den sidste erklærede dog, at de af Danmark besatte amråder Als og Ærø ikke blev overgivet til fællesregeringen, før man havde set, hvordan denne udførte sit hverv. Med fællesregeringens indsættelse ophørte selvfølgelig den provisoriske regering, og den slesvig-holstenske landsforsamling vedtog (21. okt.) at udsætte sine møder.

Fællesregeringen (die gemeinsame Regierung) gav samme dag, den indsattes, klart udtryk for sit sindelag ved at udstede en bekendtgørelse, hvorved den opretholdt næsten alle den provisoriske regerings love $\mathrm{cg}$ anordninger, blandt disse den slesvig-holstenske statsgrundlov. Både Stedtmann og Reedtz protesterede straks herimod, og naturligt nok blev Als og \#rø aldrig overgivet til dens styrelse. Midt i december erklærede Danmark den for en oprørsregering, hvad fællesregeringen imidlertid fandt var en fuldstændig miskendelse af dens bestræbelser, der var begrundede i dens bedste cverbevisning. Sidst i februar 1849 skred vor regering til at opsige våbenstilstanden, men fjendtlighederne begyndte først i begyndelsen af april. Den 26. marts 1849 aflastes fællesregeringen af et af den tyske centralmagt i Frankfurt udnævnt statholderskab.

Tænker man på den i Malmøkonventionen aftalte fællesregering, havde slesvig-holstenerne grund til at være tilfredse med 
den regering, som det var endt med. Og de dansksindede havde skellig årsag til utilfredshed og skuffelse. I en indberetning fra politimester Krohn fra slutningen af 1848 hedder det også, at de første efterretninger om fællesregeringens optræden i forhold til "die Landessache" gjorde et lammende og nedtrykkende indtryk på de dansksindede. Men, fortsætter Krohn, modlasheden veg snart pladsen for den gamle forbitrelse, for det gamle indgroede had. Hertil bidrog agitationen fra Als, men tillige fællesregeringens "forsonlige optræden“. Hvad Krohn ønskede, var selvsagt en energisk optræden også fra den nye regering i slesvig-holstensk ånd. Selv fortsatte han i det engang indslåede spor: forsøget på ved politiregimente at holde alle danske tilkendegivelser nede.

Omkring midten af november fik Krohn underretning om, at der i Flensborg cirkulerede en adresse, som indeholdt en protest mod Slesvigs forbindelse med Tyskland. Skolebud Hans Jacob Nissen Rabe, kendt under navnet Jacob Alldag, gik fra hus til hus og samlede underskrifter. Da han af politibetjent Isensee blev opfordret til at indfinde sig hos Krohn, gjorde han sig usynlig. Krohn indledede imidlertid straks forhør over andre personer, som han fik angivet som virksomme ved protestadressen. Den 20. afhørtes skibsfører Hans Bladt og bødker Hansen, der begge havde underskrevet og samlet underskrifter, og den 21. blev den deputerede borger F. N. Friedrichsen afhørt, da en angiver havde udlagt ham som forfatter af adressen. ${ }^{7}$ ) Dette benægtede Friedrichsen og oplyste, at adressen skulde være sendt fra Sønderborg, og at den skulde tilbage til kammerherre Riegels på Als for at sendes til København. Sit eksemplar af adressen havde han sendt Riegels, efter at det var forsynet med underskrifter $i$ hans hus. Da det yderligere oplystes, at et stort antal protester skulde være sendt med den ugentlige vogn, der

7) Datoen for forhøret er i Krohns akter fejlagtig angivet som den 22. I forh $\varnothing$ ret omtales die morgen erscheinende Nummer des Wochenblatts«, der kom den 22. Desuden nævnes forhøret i den nedenfor omtalte skrivelse af 21 . til den slesvig-holstenske regering. 
samme dag afgik til Sønderborg, blev Isensee sendt efter vognen, som han indhentede $i$ Gråsten. Han fandt dog ingen protester og vendte hjem med en lang næse. - I samme forhør meddelte udgiveren af "Flensburger Wochenblatt", bogtrykker Jäger, at de deputerede borgere Friedrichsen, Hans Jensen, P. A. Petersen og Nøbbe samt værten Kayser havde indleveret en annonce om, at der lå en protest mod Slesvigs tilslutning til Tyskland til underskrift hos dem. Men annoncen var indleveret for sent til, at den kunde optages i det forste nr. Denne aktion viser, at Krohn havde ret $\mathrm{i}$ sin udtalelse om, at modløsheden hos de dansksindede ikke varede så længe.

Den 20. sendte Krohn den slesvig-holstenske regering på Gottorp en beretning om protestens cirkulation og meddelte, at ifølge et rygte var der i Flensborg (med Jørgensby og Hulvejene) indsamlet omkring 1000 underskrifter. Dagen efter indberettede han yderligere Friedrichsens udtalelse om, at protesten udbredtes af Riegels, og mente, at man burde rejse tiltale for landsforræderi og indlede en kommissarisk undersøgelse. Han henstillede til regeringen at udstede en bekendtgørelse om sagen, hvorpå han selv i "Wochenblatt" vilde offentliggøre en advarsel, så man $\mathrm{i}$ hvert fald i fremtiden kunde rejse tiltale. Næste dag igen skrev han bl. a., at protesten efter sikkert forlydende skulde være underskrevet af flertallet af de deputerede samt af rådmændene Schwennsen og Schmidt og borgmester Lorenzen.

Den slesvig-holstenske regering imødekom Krohns onske og meddelte ham den 23., at da protesterne skulde tilbagesendes danske myndigheder, var de ganske utilstedelige. Krohn burde offentliggøre en advarsel herimod, hvad han ikke lod sig sige to gange. Den 24. udstedte han en advarsel mod enhver deltagelse $\mathbf{i}$ de danske agitationer (die Umtriebe) og med trusel om at skride skarpt ind mod sådanne. I denne forbindelse kan det nævnes, at ikke alle slesvig-holstenere billigede Krohns taktik. Sáledes skrev borgmester Georg Schow i Åbenrå den 24. til 
Krohn, at noget dummere kunde man ikke gøre nu, da protesterne allerede var afsendt, end at publicere en advarsel. Thi danskerne kunde da hævde, at uden dette politiforbud vilde protesterne have fået langt flere underskrifter, agitationerne var allerede efter de bestående love strafbare, og en advarsel vilde gøre det vanskeligt at opdage dem. Han, Schow, vilde straks skride ind mod underskriverne, hvis han fik fat $i$ et eksemplar af protesten!

Da bogtrykker Jäger havde meddelt Krohn, at Friedrichsen og P. A. Petersen igen havde forlangt den førnævnte annonce om protesten indrykket, svarede politimesteren (den 23.), at skete dette, vilde hele Wochenblatts oplag blive konfiskeret.

Den 24. måtte P. A. Petersen i forhør. I modsætning til Friedrichsen forklarede han, at hensigten var at sende protesterne samlede til London for her at påvirke fredsunderhandlingerne. Det var forste gang, at han hørte Riegels' navn nævne, og det var en fejltagelse, hvis Friedrichsen havde sendt et enkelt eksemplar til Riegels. Hvem der havde forfattet protesten, vidste han ikke. Krohn mente af P. A. Petersens forklaring at kunne slutte, at det danske parti på en eller anden måde var blevet advaret og nu anlagde den taktik at fremstille „die Umtriebe“ som uden forbindelse med dansk påvirkning. Han begav sig derfor til justitsråd Holm (1. assessor i politiretten), idet han straks efter afheringen af Friedrichsen privat med ham havde dreftet sin juridiske opfattelse af agitationens karakter. Holm måtte overfor Krohn indrømme, at det var muligt, at de dansksindede indirekte kunde være blevet advaret gennem ham og tilskyndede til at anlægge nævnte taktik. Han havde nemlig på spørgsmål fra flere af adressens underskrivere svaret, at udbredelsen af protesterne kun fik en forbryderisk karakter derved, at den stod i forbindelse med kammerherre Fiegels' machinationer.

I sine beretninger af 21 . og 23. november til den slesvigholstenske regering om protestsagen havde Krohn henstillet 
eller krævet, at der rejstes tiltale for landsforræderi, og at man nedsatte en kommission til at lede undersøgelserne. På højere sted nærede man dog betænkeligheder ved at imødekomme disse ønsker. I et privatbrev af 2 . dec. gav en af råderne i den slesvig-holstenske regering på Gottorp, E. Lesser, ganske vist Krohn meddelelse om en række foranstaltninger, der blev truffet til imødegåelse af danske agitationer, bl. a. skulde Krohn (og amtet) få stillet et kommando på 24 md. infanteri til disposition til gendarmeritjeneste. Men det var endnu uafgjort, skrev I.esser, om og hvordan der vilde blive skredet ind mod underskriverne af protesten: „Fra den strenge rets standpunkt kan der sikkert rejses stærke tvivl (m. h. t. en indskriden), da vor kriminallovgivning åbenbart er blevet langt bagud for tiden. Men lad os afvente, hvad overretten bestemmer herom. Jeg troede at have udfundet en måde, således at man kun havde behøvet at skride ind mod anstifterne, kolportører osv., men nægter ikke, at der kan rejses betænkeligheder herimod. Gerne sá jeg, at man undgik et monstrum af en undersøgelse, og er enig med dig $i$, at der kun skal vises alvor ...". Nogle dage senere meddelte den slesvig-holstenske regering imidlertid Krohn, at overkriminalretten ikke fandt sig kompetent til at anordne en kommissarisk undersøgelse, men den havde pålagt de øvrigheder, som havde med kriminalsager at gøre, at iagttage det fornødne m. h. t. nævnte agitationer.

Monstrumundersøgelsen blev nu ikke undgået. Krohn fortsatte ufortrøden med forhør gennem december måned 48 , januar 49 og ind i februar, men sagen løb åbenbart ud i sandet. Lidt udbytte fik Krohn dog, bl. a. blev et par kolportører straffede for urigtige vidneforklaringer. Men de mere fremtrædende flensborgere, som havde været virksomme i adressebevægelsen, lykkedes det ham ikke at få ram på. Tværtimod gik disse til modangreb under påberåbelse af de ved den slesvig-holstenske statsgrundlov af 15 . sept. tilsikrede friheder. Da Krohn havde arresteret en underordnet tjenestemand ved vejvæsenet, tilbød 
den dansksindede rådmand Claus Schwennsen således under henvisning til statsgrundloven at stille kaution for den fængslede, hvad Krohn afviste. Schwennsen klagede til overretten, hvorefter Krohn midt i december måtte forsvare sin optræden. Begrundelsen for ikke at have villet løslade den arresterede mod kaution fandt Krohn i, at der var tale om landsforræderi: „De omhandlede protester er sat $i$ gang af en fjendtlig magts embedsmænd, de skal tjene til fordel og til begunstigelse af denne fjendtlige magt, true Slesvig-Holstens selvstændighed og enhed". Schwennsens udtalelser om, at hans optræden var ulovlig, fandt han strafbare og bad overretten skride ind derimod. I øvrigt klagede han bittert over, at hans personlige ære fortsat blev angrebet på den skammeligste måde ved korrespondancer fra Flensborg (i danske blade), og han mente ikke at turde afrise, at der var fare for hans iiv. Sit embede havde han sandelig kun modstræbende overtaget, og fordi han måtte. Schwennsens andragende blev derefter afvist af overretten. Denne opfyldte dog, så vidt ses, ikke Krohns ønske om at skride ind mod Schwennsen.

Også F. N. Friedrichsen, en af adressebevægelsens hovedmænd og en af de mest uforfærdede dansksindede, klagede over Krohn. Klagen gjaldt Krohns forbud mod den førnævnte bekendtgørelse i Wochenblatt om protesten, men noget resultat opnåede Friedrichsen dog ikke. Han havde i øvrigt flere sager for deltagelse $\mathrm{i}$ danske demonstrationer løbende, og i efteråret var han blevet suspenderet som deputeret, hvad der fremkaldte en kraftig protest fra 11 andre deputerede. I begyndelsen af februar 1849 måtte han møde til et længere forhør hos Krohn dels $i$ anledning af sin deltagelse i flagdemonstrationen i sept. og omstemplingen. i Sønderborg af hans skib „Die zwei Gebrüder" og dels i anledning af protesten. Om denne forklarede han, at han ikke nægtede at have opfordret forskellige borgere til at have protesten liggende til underskrift, men han så ikke noget lovstridigt heri. Han hævdede ikke at have stået 
i forbindelse med Riegels, men anså forresten heller ikke sådant for strafbart. Da Krohn kom med sit, at Danmark var en fjendtlig stat, svarede Friedrichsen, at denne betragtning kunde han ikke anerkende: vort forhold til Danmark var noget, som endnu skulde ordnes.

I forhørene møder vi en række andre dansksindede flensborgere, der havde virket for at samle underskrifter på protesten. P. A. Petersen vedstår at have underskrevet sammen med nogle ligesindede, værten Iver Iversen Rasch har underskrevet og haft protesten liggende fremme i sit lokale, købmand Jochimsen har selvsagt også skrevet under, det samme har den deputerede, farver Hans Jensen og værten M. H. Kayser, J. J. Nøbbe har fået et eksemplar forsynet med underskrifter, mægler Christian Synderup har samlet 15-20. Chausseeopsynsmand Böttcher havde været så ivrig for protesten, at han nu fandt det rådeligt at forsvinde fra byen. Den forsigtige kancellirảd Schmidt nægtede at have opfordret sine arbejdere til at underskrive, men onskede ikke at udtale sig om, hvorvidt han selv havde skrevet under.

I sammenligning med de vidtløftige og langvarige undersøgelser i protestsagen var de andre sager, som den politiske politimester $i$ fællesregeringens tid havde med at gøre, af mindre vigtighed. Men til belysning af forholdene $i$ byen $i$ denne periode er de selvfølgelig af interesse. Kort før jul måtte således købmand $\mathrm{W}$. $\mathrm{H}$. Jochimsen igen i forhør. Jochimsen var efter våbenstilstanden taget til Sønderborg, hvor han åbenbart har luftet sine danske anskuelser, men efter fællesregeringens indsættelse vendte han hjem til Flensborg, skønt Krohn havde søgt at holde ham væk. Nu blev han i det pågældende forhør gjort ansvarlig for udtalelser, som han skulde have fremsat i Sønderborg, og desuden for det forhold, at der for få uger siden i hans butiksvinduer var hængt billeder ud af fægtninger mellem danske og tyske. En eftermiddag skulde der endog være vekslet med billederne, efter at der havde samlet sig $\in \mathrm{n}$ storre 
folkehob, og derved var slesvig-holstenske troppers vrede vakt på faretruende vis. Jochimsen vedgik at have fået billederne fra København, men andre købmænd havde også haft sådanne billeder, og han havde i hvert fald ikke selv vekslet med dem!

På foranledning af Krohns spion, skomager H. C. Hansen, arresteredes $\mathrm{i}$ begyndelsen af december tømmermester Rathge, da han gjorde sig en glad lordagaften og i Hohls "Halle“ sang danske viser, bl. a. „Den tapre Landsoldat“, og kaldte tyskeme røverpak, spitzbuber, gavtyve o. 1. samt indlod sig i slagsmål med en tysksindet. Hans bedrifter takseredes til 5 dages fængsel på vand og bred.

Skomageren var også indblandet $i$ et sammenstød, der fandt sted på Skibbroen natten mellem 30. nov. og 1. dec. Ifølge politimester Niemanns fremstilling holdt skibstømmermand Dannenberg, „en uberygtet mand“, næunte nat vagt ved noget skibsinventar, da han blev forulempet af en ukendt mand i selskab med den „,ilde berygtede skomager Hansen“. Da vægterne ved larmen ilede til - folk i de nærliggende huse vækkedes også - kaldte den ukendte, som vægterne imidlertid mente at genkende som en af Krohn til hemmelige politiforretninger brugt person (Isensee), dem for svinehunde, danske spitzbuber og hestemordere. $\left.{ }^{8}\right)$ Han var i øvrigt i høj grad beruset. Både Dannenberg og vægterne ønskede undersøgelse og streng straf for de pågældende, men Krohn, til hvem Niemann henstillede at tage sig af sagen, nærede ingen lyst til at skride ind mod sine underordnede medhjælpere. Et nyt forsøg af Niemann på at fả Krohn til at indlede undersøgelse mod Isensee strandede.

Medens dansksindede flensborgere kun mere skjult - eller når den gode flensborgergrog laste tungen - har sunget „Den tapre Landsoldat", stemte de tysksindede rigtig i med "Schleswig-Holstein". Men hvor harmeligt måtte det ikke være, når man, som det skete den 27. dec. i skomagerherberget, sang

8) Dette udtryk skyldtes nok, at en tysk officershest var blevet mishandlet. 
denne vise så at få den ledsaget af en norsk skomagersvends refrain „jagt de dütschen ut dat Land“! Resultatet blev et livligt slagsmål, som endte med, at de tyske svende forlod herberget! De tog deres tilflugt til Krohn, der tildelte modparten en skarp tilrettevisning for den skammelige forvanskning af visen.

Det er tidligere sagt, at efter Krohns opfattelse virkede fællesregeringens optræden i slesvig-holstensk ånd først lammende på de danske flensbcrgere, men at disse snart igen fattede mod. Krohn giver $i$ et brev fra begyndelsen af januar 1849 en malende skildring af de danskes stemning, sådan som den teede sig for ham. Skønt vinteren med det nye år indfandt sig i sin fulde strenghed, skriver han, var nytårsdag dog for vore dansksindede landsmænd en sand forårsdag, fyldt af nyt håb. Man så dem ile gennem gaderne med glædestrålende åsyn og ivrigt meddele hinanden den store nyhed, at danskerne, der sommeren igennem havde været ventet hos os hver søndag, nu virkelig kunde ventes meget snart. Krohn fortsætter med en omtale af, hvordan der siden de danskes flugtlignende tilbagetog fra Flensborg sidst $i$ april havde holdt sig den tro hos den med danisme opfyldte flensborgske befolkning, at danskerne engang vilde komme igen. Jo mere udsigten til virkeliggørelse heraf svandt, des mere antog troen karakter af en myte med tilbedelse $\mathrm{cg}$ præster. Der var her ingen plads for skepsis og sund menneskeforstand. Hele sommeren havde de, som sagt, forgæves hver søndag med længse’ ventet på danskerne, nen de læskedrikke, som de havde beredt for "de trætte sejrherrer", havde de måttet dele med deres tyske indkvartering. Alligevel var troen ikke gjort vaklende. Skønt de med den synkende sol den ene søndag måtte tage afsked med deres håb, så hengav de sig til et nyt, når deres profeter lovede dem "noget smukt" til næste søndag. Krohn ender sin skildring med at forklare, at grunden til, at de dansksindedes håb nu igen var blusset op, var en styrkelse af de danske tropper på Als og andre danske militære foranstaltninger. Han finder imidlertid ikke, at der for tiden kan tillægges disse større betydning. 
Sidst på året 1848 havde Krohn i en indberetning til den regeringsbefuldmægtigede Bargum givet en udførlig skildring af sit syn på de flensborgske forhold. En del af denne skildring er brugt i det foregående, og jeg nøjes her med at omtale Krohns opfattelse af tiden efter fællesregeringens tiltrædelse. Han kritiserer skarpt fællesregeringens "forsonlige, milde optræden“. Fivorvidt denne i almindelighed og særlig i de nordslesvigske landdistrikter var rigtig, lader han stå hen, men i Flensborg kunde den i hvert fald kun virke skæbnesvanger! "Således skorter det da heller ikke på talrige vidnesbyrd om, i hvilken grad danskheden igen hæver hovedet, hvordan dens tilhængere under beskyttelse af statsgrundloven, hvis fordele de nyder liden på nogen måde at anerkende den slesvig-holstenske statsborgers pligter som gældende for dem, stadig dristigere lader deres agitation komme frem i lyset og stedse mere giver deres stilling lige overfor den forsonlige regering det præg, som om der virkelig var indtrådt den fuldeste frihed til at gerere sig som danske eller slesvig-holstenske undersåtter". Krohn henviser til, hvad der er oplyst ved undersøgelserne i protestsagen, hvis landsforræderske karakter han hævder allerede er objektivt konstateret. „Men i samme grad, som danskernes mod stiger, synker de tyskes, de føler sig forladt og finder vel ikke med urette, at den mod danskerne ovede retfærdighed, der bliver gengældt så dårligt af disse, medfører en uretfærdighed mod tilhængerne af "die Landessache“."

Den slutning, Krohn i sin beretning drager, er den, at der bør gås frem med „en indtil den yderste grænse af det tilladte gående strenghed mod de trodsige og mod dem, der holder fast ved deres landsfjendtlige fremfærd", og hvor der viser sig "mangel på god vilje“ hos regeringsorganer, skal der hensynslast skrides ind. Den flensborgske magistrats holdning (neutralitet) fik i beretningen læst og påskrevet. En kraftig og selvbevidst tysk optræden var en nødvendig forudsætning for tyske tilnærmelsesforsøg mod danskerne. En sådan optræden er det, som Krohn beder Bargum støtte. 
Den opfattelse, Krohn i denne beretning giver udtryk for, at danskerne under fællesregeringen optrådte mere åbent med deres anskuelser, er rigtig nok. Det er også rimeligt her at anfore, at da der den 8. januar foretoges valg af 3 deputerede for St. Marie sogn, valgtes de danske kandidater med ca. 7 gange så mange stemmer, som de tysksindede opnåede. Danske synspunkter kom endda, som vi om lidt skal se, offentligt frem i Wochenblatt, takket være den uforfærdede broskriver Christian Hansen jun.

Omkring midten af janr. indeholdt Wochenblatt en længere artikel af købmand Caspar Andresen, der var preussisk konsul: Ansprache an meine Mitbürger, die Geschäftsmänner zunächst. Andresen klagede heri over, at partimodsætningerne i byen stadig blev skarpere og satte skel mellem venner, ja selv i familier. Man skilte sig mere og mere ud fra hinanden. Selv $i$ „Harmonien“, hvor begge parter endnu kom sammen, var det ikke længere det samme fornøjelige samvær som i gamle dage. Andresen syntes, at dette var meget beklageligt, og hævdede, at det kunde og måtte blive anderledes. Fejlene fandt han på dansk side: man burde træde åbent frem med alt - dette kunde dog nok have sine vanskeligheder, så længe Krohn var politimester! - og man burde ikke opmuntre mængden til demonstrationer, der gav sig udtryk i rudeknusen eller i at råbe „Provisoren“ som hånsord efter folk! Man burde gensidig søge forståelse. Da Andresen mente, at den egentlige grund til den herskende splid lå i en forskellig opfattelse af Flensborgs vel - om Flensborg stod sig bedst ved forbindelse med Danmark eller Tyskland - gjorde han sig til talsmand for, at Flensborg økonomisk kunde stå sig ved tilslutningen til Tyskland. Noget storre bidrag til at udjævne modsætningen mellem dansk og tysk betød Andresens artikel dog næppe.

Denne modsætning gav sig 18. janr. det udslag, at de dansksindede på en generalforsamling $i$ handelsforeningen besatte alle pladserne i styrelsen. Den tyske minoritet udelukkedes 
altså fra repræsentation her. I et nyt indlæg $i$ Wochenblatt kritiserede Caspar Andresen kraftigt dette og anbefalede at stifte en ny forening. Men han tog i øvrigt igen til orde for forsonlighed og besindighed og udtalte håb om en varig fred, og at der ikke måtte komme noget nyt 1848: Dette år ønskede vel næppe nogen tilbage, „hvor interessant det end i mangen henseende kan have været".

De af Andresen anstillede betragtninger over, hvad der økonomisk var mest fordelagtigt for byen, forblev ikke uimodsagte. Allerede først i janr. havde broskriver Christian Hansen i Wochenblatt offentliggjort en oversigt over Flensborgs skibsfart og handel i 1848 og 1847 , en oversigt, der selvsagt viste stor tilbagegang for 1848. Men i numret for 31. janr. fortsatte Hansen nu med en yderligere redegrrelse for handel og skibsfart i nævnte år. Han anførte, at Andreas Christiansen, der ejede en stor andel af den flensborgske handelsflåde, var taget til København og herfra drev handel på Ost- og Vestindien, og at flere købmænd havde solgt deres skibe [pro forma] til Danmark. Mange vilde sikkert følge deres eksempel, såfremt der mod forventning blev sluttet en fred, der var ugunstig for vor. kommercielle og industrielle forbindelse med Danmark og de danske kolonier. På den preussiske konsul, hr. Andresens umotiverede påstand om den lidet fordelagtige forretningsforbindelse med Danmark lagde Christian Hansen ringe vægt. Han anbefalede forlæggelse af den danske toldgrænse til Ejderen, og at der blev indrettet en direkte forbindelse over HusumTonning til England.

Skønt man vel må sige, at Christian Hansen fulgte Andresens opfordring til at træde åbent frem med sine anskuelser, hrstede han ingen ros. Andresen selv rykkede ud med et gensvar, hvor han navnlig beklagede sig over Hansens tone, og at han havde omtalt ham som preussisk konsul, thi det var ikke sin egen eller Preussens interesse, som han, Andresen, havde for øje, men Flensborgs. Imidlertid vilde han ikke indblandes i 
personlige stridigheder og hellere undlade at tage ordet om offentlige forhold. Men flere andre var villige til at falde over Hansen, og Wochenblatt indeholdt i de følgende numre adskillige indlæg, tit med grove skældsord, de fleste anonyme. Blandt navngivne indsendere var J. N. Soltau, der var knyttet til den slesvig-holstenske bankierforretning, og den som "vildtysker" bekendte oliemøller Nane Jürgensen. Den sidste lagde i sin polemik ikke fingrene imellem: Selv om nogle kobmænd ved en for Danmark ugunstig fred skulle gå til Danmark, vilde det ikke volde ham sorg! Christian Hansens hele artikel struttede af danskhed: „De og konsorter synes at støde alt, hvad der kommer syd fra, fra dem med hænder og fø̈dder og kun at finde Deres fremtid cg lykke i Danmark. Hvorfor går De da ikke til Danmark? Her kan De udmærket undværes“. Hansen var, fortsatte Nane Jürgensen, embedsmand, og da „hele landet" havde anerkendt landsregeringen, var han pligtig at handle $i$ dens ånd. Men det gjorde han ikke. Hvormed havde han i ovrigt gjort sig fortjent til sit embede? „De blev sidste år ført til Rendsborg. Hvorfor? - det ved jeg ikke. Men der må dog have været en grund dertil, ellers vilde det vel ikke være sket. De kom tilbage fra Rendsborg, var her en kort tid og rejste til Sonderborg. Hvorfor? - fordi De måske ikke var i stand til at holde Deres mund i tømme. De var flere uger fraværende. Deres embede stod tomt. De kom tilbage og tiltrådte igen nolens volens Deres embede. Men sligt kan heller kun ske i Flensborg. Hr. Chr. Hansen jr., hvordan tør De vove her i vort fædreland offentligt at udtale: „Danmark indtil Ejderen!“ De er sandelig ikke den mand, der på nogen som helst måde kan repræsentere Flensborg!“”

Det var „eine grausame Salbe“, og flere andre indlæg var holdt i samme stil. Christian Hansen offentliggjorde endnu et indlæg, et svar på Soltaus angreb. Han meddelte heri, at han af visse grunde ikke vilde komme ind på den politiske del. Han vilde holde sig til de materielle interesser og skildrede ulyk- 
kerne for Flensborg ved en eventuel tilslutning til den tyske toldforening.

Når Caspar Andresen i sin ovennævnte artikel i Wochenblatt beklager sig ov^r de dansksindedes brug af smædenavnet „de provisoriske“, vidner det om, at det har været temmelig gængs. Også under fællesregeringen varetog Krohn selvfølgelig sine pligter til at skride ind, når tysksindede førte klage over danske skældsord. Men klager er dog vel kun fremsat i de færreste tilfælde. Nogle af disse skal omtales til belysning af stemningen.

Først i februar arresterede således nogle dragoner en bødkermester Hector, der - dog påvirket af drik - havde kaldt dem deutsche Spitzbuben, Räuberpack, Räuberbande osv. De onskede ham strengt straffet, da de $i$ byens nordlige del indkvarterede dragoner næsten hver aften hørte den slags skældscrd på gaden. - At skomager Hansen blev forulempet i et værtshus, rykket i skægget og kaldt tysk spion, er ikke værd at opholde sig over; det var han jo notcrisk. I begyndelsen af marts måtte en slagtersvend stå til regnskab for brugen af "den herværende dansksindede pøbels sædvanlige smædeord" og en anden, fordi han vilde træde alle tyske under fod. At han tiltroede sig evner til en sådan bedrift, skyldtes de stærke drikke. - Pastor Wildhagen måtte af en kone høre, at det var en skam, at han bar en sort kjole; han burde snarere have en rød, hvad der jo sigtede til hans edsbrud mod den danske konge. Præsten ønskede imidlertid ikke konen straffet, da hun senere havde gjort afbigt overfor ham.

En særdeles livlig dag oplevede Flensborg den 12. februar, da der holdtes søsession. De samlede matroser og skibstømmerfolk, hvcraf sikkert mange havde nydt en hel del brændevin, foranstaltede alle mulige optøjer og spektakler og råbte hurra for kongen af Danmark. Det rette sind til at gå i krig mod ham havde de således ikke. Det tilstedeværende militær var ikke stærkt nok til at holde orden, og der måtte udkommanderes sol- 
dater. Da en af urostifterne arresteredes, blev han befriet af andre, og en tysksindet arbejdsmand, der havde ladet en ytring falde om, at det var på tide, at militæret huggede ind, blev forfulgt og mishandlet. Borgere fra byens nordlige del beskyldtes for at ophidse urostifterne. Efter at der var rekvireret forstærkning, blev ordenen dog med lethed genoprettet. En af urostifterne erklærede karakteristisk nok for retten, at han lige så vel som alle andre havde larmet, men på sessionsdage gik det altid lystigt til. Han havde troet. det var tilladt at synge og råbe hurra.

Nyttigere for den danske konge end sådanne demonstrationer må det siges at være, at adskillige militærpligtige unddrog sig slesvig-holstensk krigstjeneste ved at tage til Danmark - som regel valgte de den korte vej til Sønderborg. Således overførtes den 8 . marts om aftenen flere militærpligtige pr. båd fra Flensborg til Sønderborg, medens andre ved arrestation hindredes i flugtforsøg. De dansksindede flensborgere fik også skylden for ved deres "løgnehistorier" at have forledt et "temmeligt enfoldigt" ungt menneske, der var soldat, til at gå over til danskerne. I det $\mathrm{i}$ foråret 1849 fra slesvigholstensk side udgivne skrift: Uber die angebliche Vertreibung dänisch gesinnter Einwohner des Herzogthums Schleswig anføres ved mange af de pågældende personer, også fra Flensborg, at de ikke er "fordrevne“, men ved flugt har unddraget sig militærpligten.

$\mathrm{Da}$ Danmark, som tidligere omtalt, allerede i december 48 nægtede at have noget med „fællesregeringen“ at skaffe, var det sandsynligt, at fjendtlighederne ret snart vilde bryde ud igen. I en skrivelse af 1 . februar 1849 til den slesvig-holstenske regering stillede Krohn med vanlig nidkærhed forslag om i dette tilfælde at udvise alle håndværkssvende, karle og arbejdsfolk, hvis hjemsted var kongeriget Danmark. Disse folks nærværelse i Sønderjyllands nordlige del styrkede nemlig den danske opposition og svækkede de tysksindedes mod yderligere 
- ud over hvad danske trusler sammenlignet med „landsregeringens" og armékommandoens "humanitet" havde gjort. Krohn nævite, at han for Flensborgs vedkommende allerede i løbet af sidste sommer havde udvist håndværkssvendene. I et privatbrev fra den slesvig-holstenske regeringsråd $\mathrm{E}$. Lesser fra begyndelsen af marts hedder det, at man kvier sig ved nu at forberede de af Krohn foreslåede forholdsregler. Men bryder krigen ud, mener Lesser, må man i hvert fald i det væsentlige gennemføre dem.

Krohns her anførte kritiske udtalelse om fællesregeringens „humanitet" stemmer godt med det syn, som de slesvig-holstensksindede anlagde. I deres øjne var fællesregeringen svag, fordi den ikke gik med til de skarpe forholdsregler mod danskerne, som de ønskede. Krohns og hans meningsfællers breve fra denne tid handler om mere politi og flere gendarmer for at holde danske agitationer nede og om, hvordan man kan hindre trafikken med Danmark og holde danske spioner og agitatorer borte fra det slesvigske fastland. Krohns bestræbelser her medførte for øvrigt et skarpt sammenstød med politimester Niemann, med hvem han ikke i forvejen stod på den bedste fod. Da Krohn i febr. bestemte, at rejsende fra eller over Flensborg til Als skulde forsynes med pas fra ham, Krohn, sendte Niemann Krohn en meget bitter skrivelse om dette nye indgreb i hans kompetence. Det var, skrev Niemann, en ny krænkelse af hans person og embedsstilling, når Krohn vilde instruere hans, Niemanns, fuldmægtig til på hans kontor at følge Krohns og ikke Niemanns anvisninger!

Sidst i februar opsagde Danmark våbenstilstanden, hvortfter krigen kunde begynde en måned efter. Åbningen af fjendtlighederne skete dog først $i$ begyndelsen af april. Også fra slesvig-holstensk side ønskede man, som sagt, den „svage“ fællesregering væk og en energisk optræden for "die Landessache". Den 26. marts sendte fællesregeringen befolkningen et afskedsbudskab, og samme dag indsattes et statholderskab, be- 
stående af Wilhelm Beseler og Reventlow-Preetz. Dette skulde regere i den tyske centralmagts navn og efter den slesvig-holstenske statsgrundlovs bestemmelser. Skønt det, som Lesser i et brev fra midt i marts skrev til Krohn, en tid havde set ud, som om slesvig-holstenerne alene måtte tage kampen op med Danmark, endte det dog med, at Preussen og Tyskland atter stillede sig bag dem. Vi vil, skrev Lesser, ikke have nødig at opofre noget. Men var stemningen både på slesvig-holstensk og dansk side krigerisk, gav Wochenblatt sikkert udtryk for talrige flensborgeres opfattelse, når den sidst i marts skrev: „Det krigerske liv udfolder sig med al sin uro, og et sådant er altid trykkende, især der hvor krigsskuepladsen måske kan være såre nærved“.

\section{Fra krigens genudbrud til indsættelsen af bestyrelseskom- missionen (3. april-25. august 1849).}

Danmark kom, da fjendtlighederne igen åbnedes, til atter at stå både over for slesvig-holstenerne og de tyske rigstropper, der i tal var den danske hær overlegne. Straks i begyndelsen af april indtraf den ulykkelige kamp ved Ekernførde mellem danske krigsskibe og tyske landbatterier, hvor linieskibet Christian VIII sprang i luften og fregatten Gefion erobredes af fjenden. Sejren over „den danske sømagt“ - eller dog en del af denne! - forherligedes af statholderskabet i en svulstig proklamation. En ny sejrsproklamation fik statholderskabet anledning til at udsende efter slaget ved Kolding den 23. april. En dansksindet flensborger, der havde forsynet en sådan offentlig opslået proklamation med den upassende tilføjelse „lauter Lügen und Wind“, idømtes et længere ophold i tvangsarbejdsanstalten.

Måske var det disse sejre, der opflammede de tysksindede flensborgere, som var samlede $i$ foreningen "Casino", til at gå angrebsvis til værks mod magistratens „neutrale“ holdning. Sidst $\mathbf{i}$ april bemyndigede foreningen på en ekstraordinær ge- 
neralforsamling en deputation, der bl. a. bestod af skrivelærer Burgwald og J. N. Soltau, til at rette en henvendelse til magistraten. Man onskede omgående svar på følgende tre spørgsmål: 1. Hvorfor ringes der ikke med kirkeklokkerne ved militære begravelser, og hvorfor har kapellet på kirkegården indtil for nylig været stængt for ligene af vore krigere, „som har fundet døden for vor sag på ærens mark“, således at det var nødvendigt offentlig at kritisere dette forhold (det skete i Wochenblatt 25. april), før det blev ændret. 2. Hvorfor sættes der ikke en stopper for de forbrydelser, der begås mod vore faldne krigeres grave, idet kranse og bånd rives af, og blomsterne nedtrampes $\mathrm{m}$. $\mathrm{m}$. Kirkegårdsopsynsmanden burde for længst være draget til ansvar for dette. 3. Hvordan kan det være, at det kun er her i Flensborg, at det tyske flag ikke vajer fra tårne og offentlige bygninger, og hvad er grunden til, at de ofte udtalte onsker om en forandring her stadig ikke er opfyldte.

Henvendelsen blev den 1. maj overrakt borgmester Callisen personlig og foreløbig besvaret af ham. Det skyldtes en misforståelse, at kapellet ikke hidtil var blevet åbnet, udtalte han. M. h. t. gravskænderier lovede han, at der vilde blive skredet skarpt ind. Klokkeringningen var formodentlig undladt af hensyn til bekostningen herved. At hejse flag på kirketårnene forekom ham upassende, og det var han ubetinget imod. Men han vilde ikke indvende noget mod, at flaget igen blev anbragt på rådhuset. - Indholdet af det skriftlige svar, som Holm affattede, og som gaves nogle dage senere, er stort set som Callisens mundtlige. Om flagningen hedder det her, ,at vi under de nuværende afgjorte politiske tilstande overhovedet anser udhængning af tyske faner for noget meget uvæsentligt, men i særdeleshed ikke finder det at stikke faner ud fra kirketårnene passende, og for ovrigt for at tage hensyn til de pågældende onsker har foranlediget, at den uden vort vidende og vilje forsvundne fane atter er hejst fra rådhuset".

Helt tilfreds med magistratens svar var Casino-folkene ikke. 
De bemærkede i en ny henvendelse, at de ikke kunde dele magistratens syn på spørgsmålet om at hænge faner ud fra kirketárnene. Det havde man dog gjort med Dannebrog, da kongen holdt sit indtog $\mathrm{i}$ byen. Hvorfor kunde man så ikke nu og navnlig på den 24. marts lade "den gamle landsfane“ vaje fra kirketårnene. Med den "gamle“ landsfane menes der den slesvig-holstenske, hvis alder unægtelig ikke var værd at pukke på; den var jo en helt nymodens opfindelse. Man ventede $i$ hvert fald snarest at se landsfanen vaje fra byens kran og fra Nørreog Sønderport, hvad man måtte onske for sagens, de tyske krigeres og Flensborgs skyld. Endelig skænkede man en ny fane til rådhuset i stedet for den, der var hængt ud! Denne nye henvendelse lod magistraten, så vidt ses, ubesvaret.

Til trods for Krohns politiregimente, der under statholderskabet og krigsforholdene kunde udfolde sig friere end under fællesregeringen, undlod dansksindede flensborgere ikke helt at give udtryk for deres hjertens mening. Nogle af de „forseelser", for hvilke de blev slæbt i retten, forekommer unægtelig bagatelagtige. Således hører vi kort efter krigens genudbrud, at kvinderne $i$ et hus havde drillet slesvig-holstenske soldater, der formodentlig var indkvarterede lige over for, ved at bekranse et billede af Frederik VII og holde det op og kysse det, når scldaterne viste sig! Drilleriet forte til, at en soldat og en gendarm afhentede billedet, men mere kom der vist ikke ud af sagen. En måneds tid senere måtte den i Haderslev fødte butiksjomfru hos konditor Wittmack stille hos Krohn, fordi hun havde fremsat uærbødige udtryk om slesvig-holstenske papirpenge. Samme unge dame måtte igen $i$ retten sidst $i$ juni, fordi hun ukaldet havde givet sit besyv med i laget, da en solaat overfor en anden besøgende $i$ konditoriet havde nævnt, at kom der en ugunstig fred ud af de løbende fredsforhandlinger, vilde slesvig-holstenerne måske sætte sig til modværge alene. Hun havde nemlig udtalt sin forvisning om, at i så fald vilde slesvig-holstenerne få så mange prygl af de danske, at de ikke 
vidste, hvor de skulde gøre af sig selv. Til gengæld forsikrede Krohn hende om, at øjeblikkelig udvisning af byen vilde blive hendes lod ved „den forste konstaterede utilladelige ytring om vore forhold“. På samme tid fik skomager Christian West, der havde udbredt sig om danskernes magt og om deres allierede, en skarp advarsel mod at føre slig tale og forbud mod at vise sig i offentlige lokaler.

Helt let har det ikke været for Krohns medhjælpere straks at slå ned overalt, hvor "utilladelige ytringer om vore forhold“ kunde forekomme. Da det den 31. maj rapporteredes til en gendarm, at nogle pigebørn var samlede ved toldvæsenets bygning og forlystede sig med at synge "Den tapre Landsoldat", ilede han derhen, men pigerne var borte på een nær. Hende greb han $\mathrm{i}$ armen for at føre byttet til Krohn. Der dannedes et større opløb, navnlig af kvinder, som protesterede mod at arrestere et barn for en sådan bagatel, også en preussisk husar tog bestemt afstand herfra. Da barnet desuden af lutter angst fik krampe, lod gendarmen hende endelig gå.

Skortede det således ikke Krohn og hans redskaber på energi, hvor det gjaldt om at slå ned på „dansk propaganda“, savnede Krohn denne hos regeringen. Vi ser dette af et brev til Krohn fra E. Lesser fra slutningen af april. Jeg forstår ikke helt, skriver Lesser her, dit spørgsmål, om regeringen vedblivende ikke vil gå over til en energisk optræden. Stort set, hævder Lesser, er alt, hvad der er blevet foreslået regeringen, billiget, og det må kræves, at der foreligger et behov for de forholdsregler, som eventuelt skal træffes.

Når Krohn, som ovenfor nævnt, truede med udvisning fra Flensborg, var dette ikke tomme ord, men noget, hvortil han i adskillige tilfælde tog sin tilflugt. Det erfarer vi f. eks., da de slesvig-holstenske myndigheder i maj-juni drøfter, hvorvidt man kan transportere de udviste over grænsen til Jylland. Krohn udtaler midt i juni, at dette udmærket lader sig praktisere: det har fundet sted og gor det stadig uden vanskelig- 
heder. Han omtaler, at en række håndværkssvende er udviste, at 20. april sendtes skibskaptajn Bladt til Ribe, 2. maj den deputerede borger P. A. Petersen til Jylland og 30. maj et par folk af tyendeklassen.

I en længere skrivelse fra den sidste juni foreslog Krohn regeringen at "udvise“ den danske filial af Nationalbanken i Flensborg og det dertil knyttede personale. Krohn fremhævede, hvordan de danske sympatier, "hvorved Flensborg i den nyeste tid har erhvervet sig en så sørgelig berømmelse i vort lands historie", hovedsagelig skyldtes indflydelse fra handelsinteresserne. Her havde filialbanken spillet en stor rolle. Når den provisoriske regering, bemærkede Krohn videre, havde udstedt forbud mod bankens operationer (se ovenfor s. 171), var dette sikkert også sket mere ud fra politiske end fra retslige synspunkter. Men forbudet havde kun haft ringe følger, da banken uhindret indtil dato havde fortsat sin virksomhed, om end i noget ændret form og med afsavn af nogle mindre fordele. Derfor foreslog Krohn en "fuldstændig udvisning“, hvad der også forholdsvis let lod sig praktisere under krigen og den herskende blokade, hvor handelen lå stille. Til gengæld burde den slesvig-holstenske landsbank stottes.

Til en sådan udvisning kom det dog ikke. Fredsforhandlingerne mellem Danmark og Preussen stod på dette tidspunkt foran deres afslutning. 6. juli led slesvig-holstenerne deres store nederlag ved Fredericia, og 10. juli enedes Preussen og Danmark om fredspræliminærer og en våbenstilstand, hvorunder Slesvig skulde regeres af en fælles bestyrelseskommission med en engelsk opmand. Nordslesvig (med Flensborg) skulde besættes af svensk-norske tropper, Sydslesvig af preussiske.

Et par dage efter Fredericia-slaget kom det til demonstrationer i Flensborg, da danske krigsfanger førtes gennem byen. Efter gendarmernes rapporter fandt der mange "uordener" sted af de dansksindede indbyggere, og gendarmerne, som ledsagede transporten, udsattes for forhånelser. Disse har dog mest 
bestået $\mathrm{i}$ hånlige fagter fra forsamlede kvinder. En af de tilstedeværende mænd tillod sig dog også at råbe til fangerne: „Lever da lykkelig og kom snart igjen“, hvilket tilråb skurrede slemt $\mathrm{i}$ gendarmernes øren - og lennedes med hug.

Efter Frediericia-slaget og Berlinoverenskomsten måtte Flensborgs danske føle større fortrøstning til fremtiden. I slesvig-holstenske kredse dukkede derimod bange anelser for fremtiden op, hvortil også den almindelige politiske udvikling bidrog. Revolutionsbølgen fra 1848 var ved at dale. Allerede midt i juni havde borgmester Georg Schow i Åbenrå således $i$ et brev til Krohn udtalt sin bekymring i anledning af fredsrygterne og sin væmmelse ved tilstanden i Tyskland. Samtidig udtrykte han dog håbet om, at statholderskabet og landsforsamlingen vilde holde orene stive og ikke selv give op; så skulde landet nok holde fast ved dem.

Dette blev for så vidt også tilfældet, som både statholderskabet og landsforsamlingen kraftigt protesterede mod vábenstilstandsoverenskomsten og prøvede på enhver vis at hindre dens udførelse. I tiden inden de svensk-norske troppers ankomst opretholdt statholderskabet sit regimente i Nordslesvig ved at oge tallet af gendarmer, således ved at gøre dragoner til gendarmer. I et brev herom 30 . juli fra Lesser til Krohn hedder det, at det dog er ham tvivlsomt, hvor længe man vil kunne drage nytte af denne tilstand. Efter al sandsynlighed, mener han, vil man ikke stort længere kunne gøre regning på de preussiske officerer, derved vil man miste hæren og stå værgeløs overfor våbenstilstandskonventionen. Ganske vist frembyder denne så mange "hager", til hvilke man kan klamre sig fast for at fremkalde strid, og sagen vil derfor trække $i$ langdrag. Alligevel kan man vel næppe betvivle, ender han, at bestyrelseskommissionen $i$ en eller anden form vil træde $i$ virksomhed.

I et omtrent samtidigt brev fra krigsminister Jacobsen til Krohn omtales det spørgsmål, hvorvidt man burde optage de- 
sertører fra den preussiske hær $i$ den slesvig-holstenske. Jacobsen tager imidlertid bestemt afstand fra denne tanke, da det - om det skete i større stil - vilde gøre ikke blot Preussen, men også alle andre regeringer til statholderskabets fjende. I den stilling, i hvilken Slesvig-Holsten nu befandt sig, skulde Jacobsen gerne, udtaler han, tilråde de mest beslutsomme revolutionære midler, men der var overalt indtrådt den største ebbe i folkestemningen. Kastede man sig i armene på revolutionen, udsatte man sig for miserabelt at gå til grunde.

Som stemningen i slesvig-holstenske kredse var overfor våbenstilstanden, er det ikke underligt, at man frygtede for antipreussiske demonstrationer, når de preussiske tropper $i$ henhold til overenskomsten forlod Nordslesvig - og jo i øvrigt for den store parts vedkommende hertugdømmerne. Den 20. juli fandt statholderskabet sig foranlediget til at udsende en opfordring til at modtage de hjemvendende preussiske og tyske tropper venligt: „De er tyske som vi, besjælede af håbet om, at det vil lykkes, selv om også efter tunge lidelser at grundlægge Tysklands enhed og styrke, de beklager ikke mindre end vi den påbudte tilbagemarch." I en skrivelse dagen efter fra krigsdepartementet til borgmester Callisen opfordres denne også kraftigt til at undertrykke eventuelle demonstrationer mod de tilbagevendende tyske, særlig preussiske tropper. Omvendt hører vi, da tropperne i begyndelsen af august drager syd på gennem Flensborg, at de dansksindede her skulde have haft til hensigt at overrække dem blomsterkranse og dannebrogsfaner, hvad de kommanderende over tropperne dog bestemt frabad sig!

Statholderskabet opretholdt, som sagt, sit regimente i Nordslesvig og Flensborg ved hjælp af gendarmerne. Det udskrev også i tiden mellem våbenstilstanden og bestyrelseskommissionens indsættelse rekrutter og inddrev skatter. I Wochenblatt hedder det sidst $i$ juli, at en mængde rekrutter kørte fra Flensborg til sessionen i Rendsborg; der var 12 vogne, pyntede 
med flag og hilste med glæde. Bladet tilføjer dog, at en del rekrutter har forebragt grunde for udeblivelse, og nogle skal have absenteret sig: „man siger ellers, at der nu skal træffes strengere forholdsregler [imod sådant]". Af en meddelelse, som bladet har i nummeret for 22. aug., fremgår det, at af de 20-årige, som da skulde udskrives, er adskilligt over halvdelen udeblevet: „Neptun er formodentlig blevet deres skytsgud, hvorvidt hans beskyttelse er vedvarende sikker, vil følgen vise“. Det skulde dog holde denne gang.

Den 2. maj havde statholderskabet til bestridelse af omkostningerne ved rigstroppernes forplejning udskrevet et tvangslån at betale i fire rater (1. juni, 1. juli, 1. aug. og 1 . sept.). Under de ændrede forhold kunde villigheden i Flensborg til at udrede dette ikke være alt for stor. Allerede 7. juli havde deputeretkollegiet udtrykt onske om, at der ikke blev indsendt flere penge end højst nødvendig. I begyndelsen af august meddelte nu det slesvig-holstenske finansdepartement den flensborgske magistrat, at den, om den vilde undgå eksekution, måtte indsende den til 1 . aug. forfaldne rate af tvangslånet inden tre dages forløb. Magistraten - med undtagelse af rådmand Schwennsen - besluttede at imødekomme dette krav. Derimod nægtede deputeretkollegiet det $\mathrm{i}$ et møde, hvor 18 medlemmer var til stede; 3 af disse stemte dog med magistraten. Kollegiets majoritet henviste i sin beslutning også til de ved våbenstilstanden ændrede forhold. Uenigheden $\mathrm{i}$ bykollegierne indbragtes derpå for den slesvig-holstenske regering på Gottorp, der selvfølgelig tog magistratens parti. I et nyt møde af deputeretkollegiet, hvor 21 medlemmer var til stede, fastholdt dettes majoritet sit standpunkt og gjorde magistraten ansvarlig for indsendelsen af pengene. Karakteristisk nok fremsatte majoriteten samtidig det ønske, at magistraten skulde søge om, at Flensborg blev gjort til sæde for bestyrelseskommissionen.

De talrige flensborgere, der under det slesvig-holstenske 
styre havde måttet forlade deres hjemby, så med længsel hen til det tidspunkt, da forholdene skulde gøre det muligt for dem at vende hjem. Vi kommer, så snart vi kan, hedder det $i$ et brev fra sidst $i$ juli fra en flensborger, der da opholder sig $i$ Sønderborg, til hans kone, som er forblevet i Flensborg. Brevet er som flere andre beslaglagt af politimester Krohn. Et af de andre beslaglagte breve er ligeledes fra en flensborger $i$ Sønderborg til hans "hjertensallerkæreste kone“, bosat i Flensborgs "Norden“. Han håber at høre, at konen er rask, for så er alt godt, selv om slesvig-holstenerne også har ødelagt meget: „Den kære Gud vil hjælpe os igen, de vil alle få deres løn, Gud vil sikkert ikke lade noget ubelønnet. Kære Mine! Sørg bare ikke, men bliv ved med at pynte de danske grave, thi de er det værd, og bliv nu ikke træt, min engel, thi danskerne trættes ingensinde, de vil holde ud, indtil de har befriet os". Brevet ender med hilsener til alle venner og kendinge og løftet om, at han snart vil være i deres midte.

Der gik dog endnu nogle uger hen, før Krohns politiregimente kom til fald. Men midt i august fyldtes Flensborg havn påny af skibe, førende det af den store befolkning elskede Dannebrog. Det var danske handelsskibe og dampskibe med den kommende bestyrelseskommissions folk. Og samtidig vendte de flensborgske grønlandsfarere hjem. Rheden frembød igen et skue, som kunde fryde flensborgske købmænds hjerter. Der forløb endnu en halv snes dage med tovtrækning mellem de danske og preussiske udsendinge, og hvor slesvig-holstenerne af al magt søgte at hindre udførelsen af våbenstilstanden. Endelig den 25. august kunde bestyrelseskommissionen, hvis danske repræsentant var Tillisch, installere sig i Flensborg. Det slesvig-holstenske styre, hvis mænd havde set forhold og hændelser i den gamle kongelig-danske sø- og handelsstad som i et troldspejl, - dette styre var forbi. 


\section{Kilder.}

Den foregående fremstilling bygger væsentlig på utrykt materiale fra Landesarchiv für Schleswig-Holstein, Gottorp slot, Slesvig, fra Flensborg byarkiv og fra det danske Rigsarkiv. Det første sted beror således politimester Krohns arkiv. Vigtigst af dette er C XIX. 1, nr. 81. Akten betr. Untersuchungen der Polit. Polizei in Flensb. Mai 1848 bis Sept. 49, men også nr. 80, 82 og 86 er brugt. Smst. findes overpræsident Liliencrons arkiv (Ábteil. 167 (C XII), 1 nr. 504 a). Endvidere er fra Landesarchiv benyttet A XIV, nr. 3. Akten der Civilbehörde zu Kiel (heri Ahlmanns skrivelse 4/4 1848 til den prov. reg.) og A XIV, nr. 120 (Conv. V. B. 5. Stadt Flensburg) (heri bl. a. Jacobsens skr. 5/4 1848 til den prov. reg.) samt C XIX, 1, nr. 85.

I Flensborg byarkiv er benyttet bykollegiernes protokol (nr. 236, 3) og deputeretkollegiets privatprotokol (nr. 238, 1), endvidere: $\mathrm{nr}$. 148. Akta betr. Korrespondenz mit der prov. Regierung in allgemeinen Verwaltungssachen 1848; nr. 911, fasc. 1. Akta betr. Erhebung SchleswigHolsteins gegen Dänemark. 1846-49 samt nr. 862, fasc. 2. Akta betr. Innere Unruhen $u$. Aufruhr ... 1848. 1851-65. I arkivets håndskriftsamling findes $i$ afskrift Flensburger Chronik der Jahre 1848-73 des Kaufmannes N. C. F. Lüders .

Af arkivalier fra det danske Rigsarkiv skal særlig nævnes regeringskommissionen af $3 / 41848$ for hertugdømmet Slesvig (heri navnlig embedsmændenes erklæringer og akterne vedr. amtmand Warnstedt) og Slesv. min. 1. dpt., afd. 793. $2 \mathrm{nr}$. 220 (heri afskrifter af akterne vedr. foretagelse af valg til den tyske nationalforsamling). Fra Frederik VII.s arkiv er brugt Holsts beretning om slaget ved Bov. - I Riksarkivet i Stockholm er brugt Ur Danica. 3. Konsulers skrivelser. Flensburg 1848-49.

Af trykt materiale skal foruden Neergaards store værk , Under Junigrundloven. I, der giver den almindelige baggrund for fremstillingen, nævnes følgende:

Flensburg. Darstellung seines Zustandes $u$. Verhaltens während des schleswig-holsteinischen Aufruhrs, entworfen von einem Flüchtling. Herausgg. von D. E. Rugaard. 1848.

Darstellung derjenigen Charactere, welche in ... Flensburg an unserer ... Revolution thätigen Antheil genommen haben. Von einem stillen Beobachter. Flensburg 1850.

Flensburger Wochenblatt für Jedermann. Zu bekommen bey J. D. Jäger. 1848-49.

Bericht über die Verhandlungen der vereinigten Ständeversammlung der Herzogthümer Schleswig-Holstein 1848.

[Valentiner]: Erinnerungen aus Kriegs- und Friedenszeiten. Altona. 1852.

Slesvigske Provindsialefterretninger. I, s. 292 ff (Fr. Graaes artikel om Kruse).

M. F. Blaunfeldt: Minder fra S $\varnothing$ nderjylland. 1876.

Sønderjydske Aarbøger 1902, s. 147 ff (Brev fra toldkontroll $\phi \mathrm{r}$ Svend Møller 15/4 1848).

Elisabeth Kardel: Die Stadt Flensburg und die politischen und nationalen Zeitströmungen um die Mitte des 19. Jahrhunderts. Flensburg 1929. (Sml. Hist. Tidsskr. 9. r. VI, s. 476 ff).

Andreas Lorck Schierning: Die Chronik der Familie Lorck. Schicksale und Genealogie einer Flensburger Kaufmannsfamilie aus vier Jahrhunderten. 1949. 